\title{
A copper alloy light cannon from Grodno: an example of early firearms from Eastern Europe
}

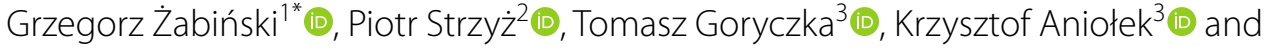 \\ Ewelina Miśta-Jakubowska ${ }^{4}[$
}

\begin{abstract}
The paper discusses a recent find of a copper alloy light cannon discovered at the Old Castle in Grodno, Belarus. The research aim was to analyse the artefact in all its possible aspects, including archaeological and historical contexts, possible analogies, and the gun's technology of manufacture. This latter was done against a broad comparative background of what is known on manufacturing technologies of late medieval and modern period copper alloy firearms. First, the archaeological and historical contexts of the discovery are dealt with. Then, the morphology and typochronology of the cannon are discussed and relevant analogies are proposed. Next, the technology of manufacture of the cannon is studied on the basis of metallographic examinations and EDS analyses of the metal's elemental composition. It was found out that the artefact had been made of leaded copper. The cannon can be dated with reasonable certainty to the late 14th c., as implied both by the find context, the morphology and the chemical composition of the artefact. Its deposition can be related to fights over the Old Castle in Grodno in this period, waged by Teutonic, Polish and Lithuanian forces. It can tentatively be proposed that the cannon was manufactured in a Teutonic Order's workshop, but further research is necessary to verify this supposition.
\end{abstract}

Keywords: Archaeometallurgy, Copper alloys, Middle Ages, Firearms, Grodno, Eastern Europe

\section{Introduction}

The aim of this paper is to discuss a recent find of a late medieval light field cannon that was discovered in the course of excavations at the Old Castle in Grodno, Belarus. The artefact is studied in its historical and archaeological contexts, and its chronology, typology and possible analogies are proposed. Apart from this, the main focus of the paper is the technology of manufacture of the cannon. Technological examinations included metallography (microscopic observations) and EDS analyses of the chemical composition of the gun's metal. Issues of technology are discussed against a broad comparative background of what is known about the technology of

\footnotetext{
*Correspondence: g.zabinski@gmail.com

1 Institute of History, Jan Długosz University, Częstochowa, Poland

Full list of author information is available at the end of the article
}

late medieval and early modern period guns, with special reference to chemistry of copper alloy firearms that were examined in the past. Eventually, some tentative remarks concerning a possible provenance of the gun are made and suggestions for future research on this issue are given. Although a great deal is known on late medieval and early modern period firearms, also concerning Central and Eastern Europe [1-4], the state of research on their manufacturing technologies is still unsatisfactory. Studies usually concern artefacts from single archaeological sites (e.g. [5, 6]), certain kinds of firearms $[7,8]$, technology of firearms in a given country [9], or individual artefacts (e.g. $[10,11])$. Sometimes results of technological examinations are integrated within regional studies on early gunpowder weapons (e.g. [2]). In many case studies the technology of manufacture of a given gun or a group of guns is discussed solely on the basis of results
Springer Open

(c) The Author(s) 2021. This article is licensed under a Creative Commons Attribution 4.0 International License, which permits use, sharing adaptation, distribution and reproduction in any medium or format, as long as you give appropriate credit to the original author(s) and the source, provide a link to the Creative Commons licence, and indicate if changes were made. The images or other third party material in this article are included in the article's Creative Commons licence, unless indicated otherwise in a credit line to the material. If material is not included in the article's Creative Commons licence and your intended use is not permitted by statutory regulation or exceeds the permitted use, you will need to obtain permission directly from the copyright holder. To view a copy of this licence, visit http://creativeco mmons.org/licenses/by/4.0/. The Creative Commons Public Domain Dedication waiver (http://creativecommons.org/publicdomain/ zero/1.0/) applies to the data made available in this article, unless otherwise stated in a credit line to the data. 
of XRF or EDS analyses, with no metallographic observations. What is more, these studies offer rather brief comparative remarks on manufacturing technologies of other firearms. Therefore, each comprehensive technological study of medieval or early modern period guns can be a chance to significantly broaden our knowledge in this field. This is especially significant bearing in mind an obvious fact that archaeological finds of cannons are quite rare. What is more, it is not always possible to carry out metallographic studies of surviving firearms, due to conservation restrictions related to sampling.

\section{Archaeological and historical contexts}

Architectural and archaeological examinations were carried out in 2014 and 2015 at the Old Castle in Grodno. They were aimed at preparing ground for restoration works (on the castle itself see [12-14]). 14 trenches were opened altogether. Trench 13 (trapezoid, $6.5 \times 4 \mathrm{~m}$ ) was marked out in the lookout terrace in the courtyard along a defensive wall near the castle's gate (Fig. 1). This defensive wall was constructed on top of a medieval rampart at the end of the 14th or in the early 15th c. after strong fires from the 1390s (on this phase of the stronghold see [13]). Building and refurbishment works were carried out in this area in the 16th-18th c. $[12,13]$. Due to this, the upper layers in Trench 13 were to a great degree mixed. Cultural Layers 1 and 2 were formed in result of land management works after excavations in the 1980s [13]. Both Layers 3 and 4 contained brown soil with brick rubble, fragments of roofing tiles, small vessel shards from the 16th-18th c., only Layer 3 showing presence of pieces of 20th c. garbage. Layer 5 contained sandy clay, with numerous fired clay lumps. Cannon remains (its main body and three loose parts of the chase) were found within Layer 5 , adjacent to a $70 \times 40-45 \mathrm{~cm}$ charcoal deposit showing thickness varying from 3 to $7 \mathrm{~cm}$ (Fig. 2). Numerous other fragments of melted copper were found adjacent to the cannon remains. Pottery finds that were discovered within Layer 5 were dated to the second half of the 14th c. A c. $40 \mathrm{~cm}$ thick layer of brown soil with traces of fire was found beneath the charcoal deposit. Beneath this layer there were cultural strata that were related to the construction of a defensive rampart in the 12th-13th c. (on this early phase of the stronghold see [13]; all data concerning the find context was kindly provided by Natalya A. Kiziukevič, Grodno State Historical

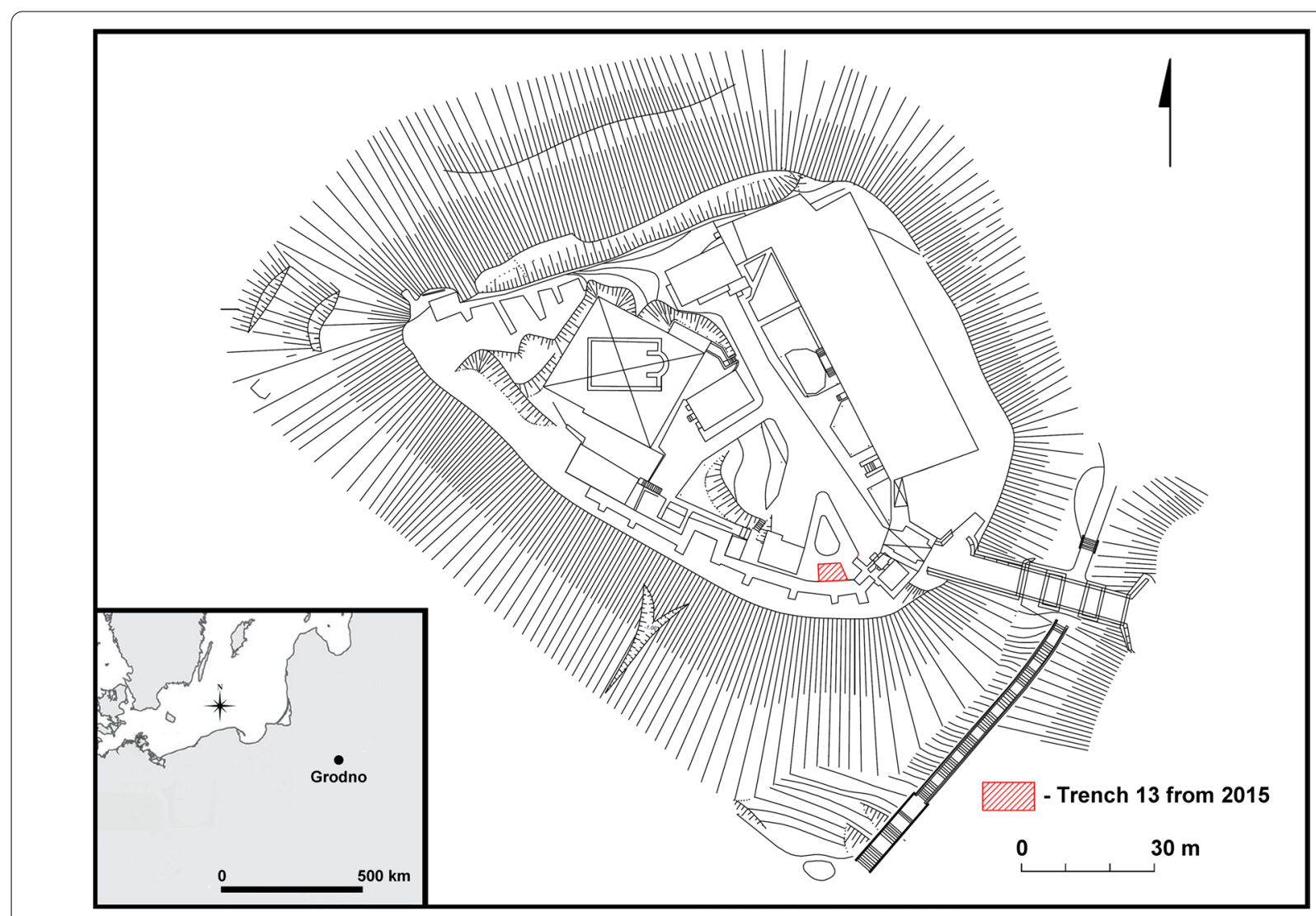

Fig. 1 Old Castle in Grodno-location of Trench 13 on the castle's plan. Drawing N. Kiziukevič, adapted by G. Żabiński 


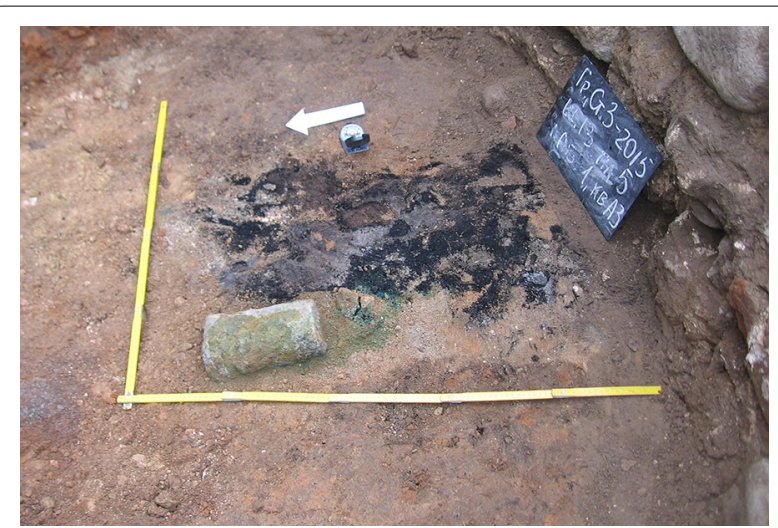

Fig. 2 Fragmented cannon from the Old Castle in Grodno in situ. One segment of the yellow folding ruler is $20 \mathrm{~cm}$. Photo N. A. Kiziukevič

and Archaeological Museum, personal communication, 20 April 2020).

In the period between the last quarter of the 14th and the early 15th c. Grodno and its vicinity became a strategic area. This was a result of political contacts between the Grand Duchy of Lithuania and the Teutonic Order, with special stress on complex relationships between the Lithuanian Duke Jogaila (since 1386 Władysław II Jagiełło King of Poland) and his cousin Duke Vytautas. In Summer 1378, the Order attacked Lithuania and devastated the region of Podlachia with the strongholds of Grodno and Brest ([15], p. 593, 597; [16], p. 107; [17], p. 48). In 1384, Vytautas abandoned the Order's side and received in return these two strongholds, as well as other territories ([17], p. 89-93).

However, in 1389 Vytautas rose against Władysław. After failing, he allied again with the Order in 1390 ([17], p. 128-133). In January 1390, the Order launched another military expedition and seized several strongholds, including Grodno and Brest. Władysław counterattacked, and on 16 April 1390, Grodno was taken by Polish-Lithuanian troops. Both Polish and Teutonic sources mention the use of firearms by the besieging forces ([15], p. 640-641; [16], p. 162-163; [18], p. 162163; [19], p. 180-182); see also ([17], p. 134). However, in early December 1391 the castle of Grodno was seized again by the Order's forces and was ceded to Vytautas. Firearms may have been used by both parties during the siege ([15], p. 646-647; [18], p. 174-176); see also ([17], p. $137-138$ and [20], p. 166).

In October 1392, after another reconciliation between Vytautas and Władysław, the Order invaded Vytautas' lands and in early January 1393 Grodno was razed to the ground. Artillery was extensively used by the besiegers ([15], p. 649; [16], p. 185; [18], p. 185; [21], p. 623); see also ([17], p. 172 and [20], p. 166). On 23 April 1398, a treaty was made between the Order and Vytautas, who ceded the region of Samogitia to the Order ([17], p. 179-181). However, after another reconciliation between Vytautas and Władysław, in Spring 1401 it came to an anti-Teutonic uprising in Samogitia. In February 1402, the Order's troops ravaged the vicinity of Grodno ([18], p. 256, 264-265; see also [17], p. 253-255).

Therefore, on the basis of the archaeological stratigraphy and the historical evidence, it can be assumed with reasonable certainty that the cannon found in Layer 5 may have been in use during the Polish-Lithuanian-Teutonic conflicts in the last quarter of the 14th c. However, it seems much more complex to decide to which side of the hostilities it may have belonged. The proposed chronology also receives support from analogous artefacts which are dealt with below. Nevertheless, it should be borne in mind that such cannons may have remained in use for much longer, as discussed later on in this paper.

\section{Description and classification of the artefact}

The artefact in its present shape was strongly affected by fire. The artefact's surface is strongly disfigured, uneven and partially melted in many places, which obviously implies heat impact (Fig. 3A). The find consists of a main body and three detached fragments which must have originally belonged to the chase. The main body is a single cylinder that includes the breech part and the chase part, the latter being only partially preserved. Thus, the original shape of the cannon cannot be fully reconstructed. In the back part of the breech there is a primitive touch-hole, with no traces of a priming pan. A convex cross decorates one of the surviving metal fragments. This fragment perhaps comes from the muzzle and the cross (apart from its religious and symbolic meaning) may have served as a primitive aiming device (Fig. 3B). No lifting handle survived and no traces of it can be seen on the cannon's surface. A speculative reconstruction of the gun and its cross-section (as it can be proposed on the basis of similar surviving guns that are discussed below) can be seen in Fig. 4. This reconstruction was done by means of drawing a plan of the cannon and then converting it into a $3 \mathrm{D}$ image. The metrical data of the artefact are the following:

- total weight (surviving): $13.85 \mathrm{~kg}$

- total length (surviving): $287 \mathrm{~mm}$

- length of the chase (surviving): $84 \mathrm{~mm}$

- length of the breech: $203 \mathrm{~mm}$

- internal length of the powder chamber: c. $120 \mathrm{~mm}$

- diameter of the powder chamber: c. $68 \mathrm{~mm}$

- external diameter at the breech: $122 \mathrm{~mm}$

- external diameter at the muzzle (surviving): $221 \mathrm{~mm}$ 

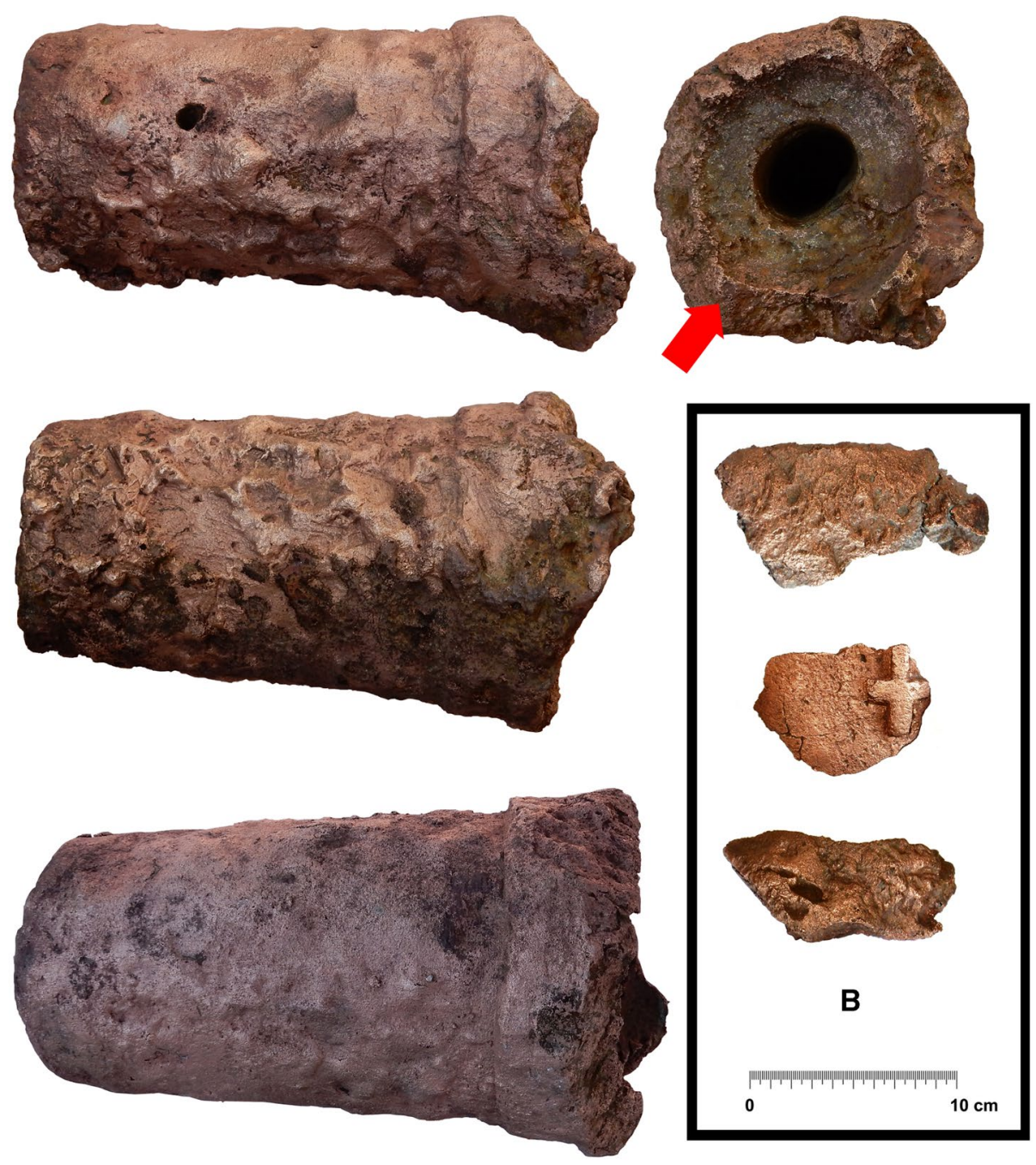

A

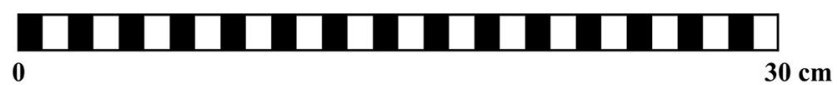

Fig. 3 Cannon from the Old Castle in Grodno-A present state of preservation; B loose fragments, including the one ornamented with the cross. Arrow indicates Sampling Location 4. Photo courtesy N. A. Kiziukevič, adapted by G. Żabiński

- internal diameter at the muzzle (calibre): c. $155 \mathrm{~mm}$

- distance between the touch hole and the breech base: $82 \mathrm{~mm}$

- diameter of the touch hole: $11 \mathrm{~mm}$

- estimated weight of the projectile: c. $5260 \mathrm{~g}$ (granite)

- putative weight of the gunpowder's charge: c. 280380 g (c. 1:19-1:14 proportion between the charge and the projectile, see ([22], p. 14 or [23], p.163).

On the basis of its calibre it can be assumed that stone projectiles were used for the gun, which thus could be termed a Steynbüchse ([20], p. 157; [22], p. 12; [23], p. 144). A gun of such a size can be classified as a light field cannon. Such cannons could be either transported on carts and then placed on wooden stands or could be mounted on wheeled carriages ([2], p. 84-92; [20], p. 159-160; [23], p. 60-61). Schmidtchen states that in the case of early stone ball cannons a usual length proportion between the calibre and the powder chamber was c. 1:2 ([22], p. 14). In this case, it is merely 1: 1.3, which may support an assumption of an early chronology of the Grodno cannon. A relative narrowness of the powder chamber (c. $68 \mathrm{~mm}$ in this case) in relation to the calibre 


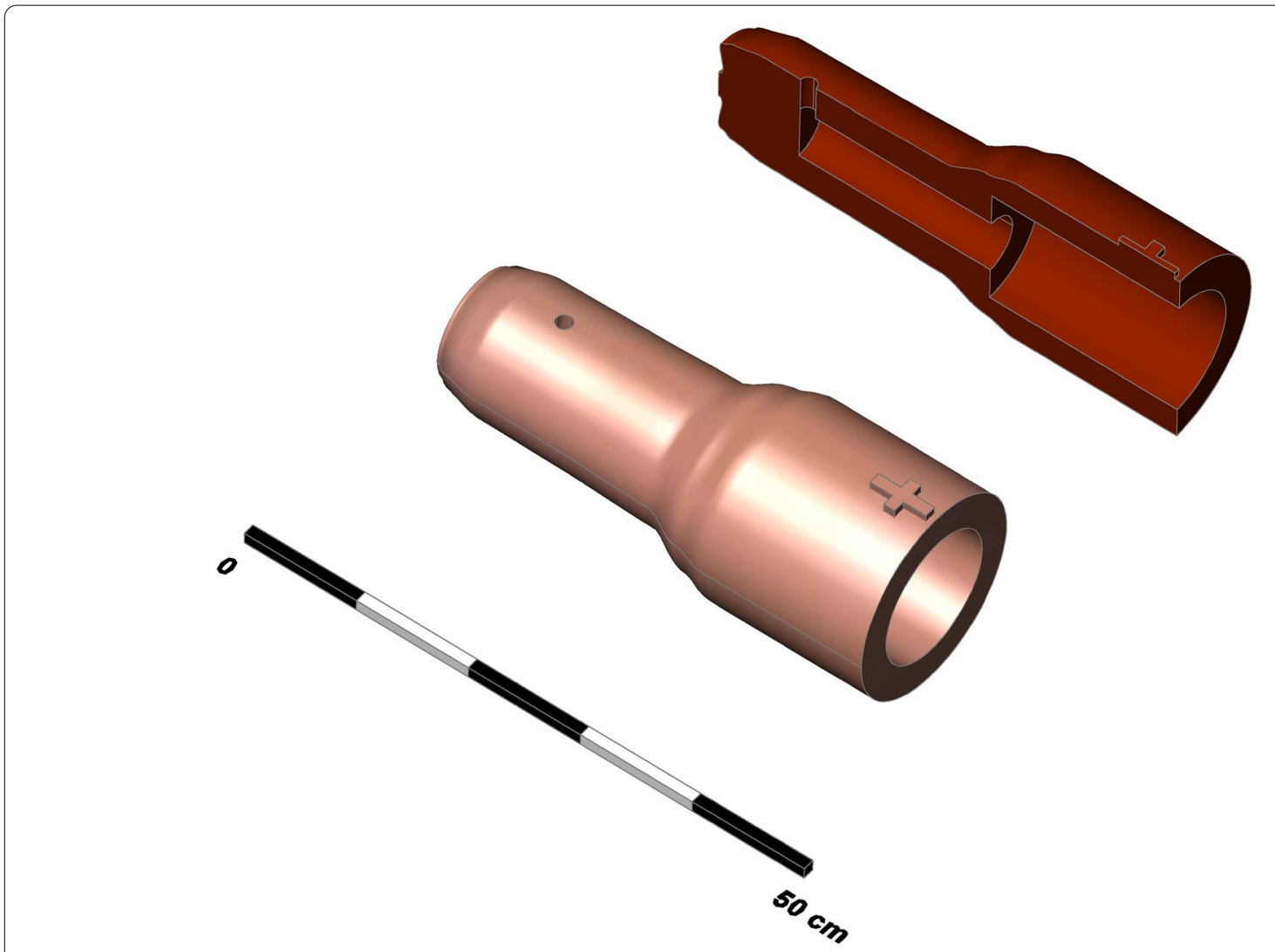

Fig. 4 Cannon from the Old Castle in Grodno—speculative reconstruction and the cross-section. G. Żabiński

(c. $155 \mathrm{~mm}$ ) is also considered a feature of early cannons of such type. This was aimed at securing a proper concentration of the explosion's impact and thus a better compression of the gunpowder charge ([22], p. 14).

\section{Early firearms in Rus}

Not much is known on the early history of firearms in Rus. The first mentions in written sources say that defenders of Moscow used guns against the Mongol siege in 1382 ([24], p. 44; [25], p. 331-332; [26], p. 74). Another record comes from 1389 and says that "in this year guns were brought from Germany" ([27], p. 444). In 1394, guns were mentioned during the siege of Pskov by Novgorod Veliky's forces ([28], p. 194). In 1408, the Mongol Khan Edigey demanded Prince Ivan Mikhailovič of Tver to support him against Moscow with guns and "tyufyaki" (тюфяки) ([24], p. 83; [29], p. 220-222; [30], p. 77-78). McLachlan supposes that "tyufyaki" were large handgonnes ([3], p. 41; see also [30], p. 85-87). According to Wilinbachow, "tyufyaki" were short-barrelled cannons analogous to early Western European bombards and they could be mounted on wheeled carriages ([31], p. 226-230, 232; see also [32]). He also maintains that the appearance of early firearms in Rus was due to
Western European influence ([31], p. 218-220). On the other hand, Kirpičnikov supposes that the new weapon reached the Rus lands both from the West and the East, the Western direction being more significant ([30], p. 78-79). In 1426, Lithuanian troops used guns during an expedition against Pskov ([33], p. 25; [30], p.79), and in 1427 , the Lithuanian army took a heavy siege cannon for an expedition against Novgorod Veliky ([24], p. 94). Many other mentions of the use of firearms are known concerning later years ([27], p. 493; [28], p. 218; [29], p. 221-222; [34], p. 185). A 1667-1671 description of firearms in Smolensk mentions a c. $250 \mathrm{~kg}$ heavy and c. $150 \mathrm{~cm}$ long "copper piščal on a wheeled carriage, cast in Russia” (Пищаль медная, в станку на колесах, Русского литья). It was provided with a Russian inscription, saying that it was cast in 1483 by a master Yakov ([35], No. 51, p. 304; see also [29], p. 225-226; [30], p. 81; [31], p. 232). This record is coherent with an opinion that gun foundries came into existence in Rus in the late 15th c. ([3], p. 41; [29], p. $223 \mathrm{ff} ;$ [30], p. 80-81).

Archaeological finds of early firearms from this part of Europe are rare. One of the earliest artefacts is an ironforged mortira found near Stary Krym in Crimea in 1885 (Fig. 5(1)). This gun is dated to c. 1375-1425 and may 

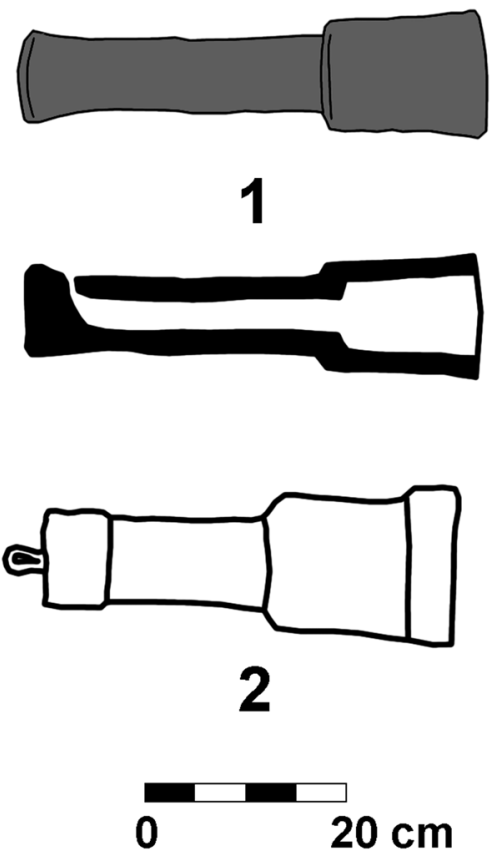

Fig. 5 Early cannons in Russian collections: $\mathbf{1}$ mortira from Stary Krym, Crimea, Military-Historical Museum of Artillery, Engineers and Signal Corps, St. Petersburg, inv. No. 9/7; 2"tyufyak"from Ržev, Tver State United Museum, Tver. After ([31], p. 229, Fig. 6). Afterdrawing G. Żabiński

be of Italian provenance, due to a strong presence of the Genovese in the peninsula. This gun is $44 \mathrm{~cm}$ long, its calibre is $8.1 \mathrm{~cm}$ and its weight is believed to be merely $11.5 \mathrm{~kg}$. Another similar iron-forged artefact of the same chronology is known from Ržev in Russia (Fig. 5(2)). This gun's total length is $46 \mathrm{~cm}$ and the calibre is $12.2-$ $12.7 \mathrm{~cm}$ ([32], p. 28, Fig. 4; [36], p. 59-60, Fig. 1; [37], p. 32, 34, cat. No. 1, Pl. 1). These guns are quite similar to the Grodno cannon, although they are iron and not copper alloy. A copper alloy cannon was discovered in the vicinity of Stary Krym in Crimea in 1966 (Fig. 6). Its total length is $895 \mathrm{~mm}$ and its calibre is $148 \mathrm{~mm}$. The find is dated to the mid-15th c. and it may be of Turkish, Genovese or local origin. The chase of the cannon is decorated with what seems to be an "Eastern" ornament (inscription?) ([32], p. 27-28, Figs.1-2; [36], p. 60-62, Figs. 3-5). Furthermore, a possibly mid-15th c. veuglaire was found in 1911 in the River Narva ([29], p. 222-223, Fig. 1).

An early handgonne dated to c. 1375-1450 was found somewhere in Central Russia. A similar gun, dated to c. 1400, was discovered in the River Lukh in the Vladimir Region ([30], p. 87-88, Fig. 41, Pl. 28; see also [38], p. 42, Figs. 28 and 33). Two fragments of hand-held gun barrels and an iron fitting of such firearms that may be dated to the late 15th-16th c. were found in the fortresses of

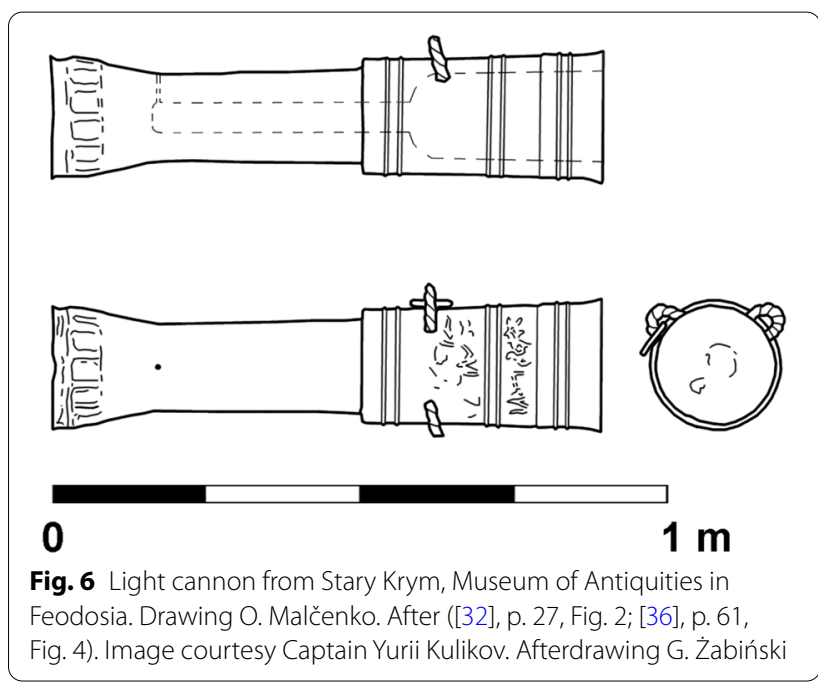

Staraya Ladoga and Orešek in North-Western Russia ([39], p. 220-224, Figs. 2.1-3). It is generally assumed that late 14th-15th c. hand-held firearms barrels from Rus were made of iron ([38], p. 24, 25, 36, 38, 39).

\section{Other analogies}

One of the most obvious analogies is an early 15th c. light field Teutonic cannon from Kurzętnik (Kauernick) in Western Prussia (now North-Eastern Poland) (Fig. 7). This gun shares the same construction design with the cannon from Grodno, that is, a narrower breech and a wider chase. Its dimensions are the following: total length $507 \mathrm{~mm}$, calibre $135 \mathrm{~mm}$, length proportion between the calibre and the powder chamber 1:1.7, weight $42.28 \mathrm{~kg}$. Technological examinations have demonstrated that this cannon was cast using copper with antimony $(\mathrm{Sb})$ and lead $(\mathrm{Pb})$ impurities. Regrettably, no quantitative analysis of the elemental content was carried out ([20], p. 155162, Figs. 1-9, p. 182, Fig. 37, p. 184-186, Fig. 38).

Attention is also drawn to a late 14th-early 15th c. copper alloy cannon of possibly Bosnian origin, now in the Museum für Deutsche Geschichte in Berlin (inv. No. W 347). Its total length is $65 \mathrm{~cm}$, its calibre is $14 \mathrm{~cm}$, its powder chamber diameter is $5.2 \mathrm{~cm}$ and the weight is $80.3 \mathrm{~kg}$. The chase is somewhat wider than the breech, although this difference is not that pronounced as in the case of the cannon from Grodno ([2], p. 87; [40], p. 36).

A convenient analogy is also offered by a light field cannon from the Zeughaus in Berlin. This gun is dated to the 2 nd half of the 15 th c. and is probably related to Burgundian-Swiss conflicts from the 3rd quarter of this century. It is made from iron bars and is provided with a holder and an additional iron ring. The barrel is $80.5 \mathrm{~cm}$ long, its calibre is $18.0 \mathrm{~cm}$ while the powder 


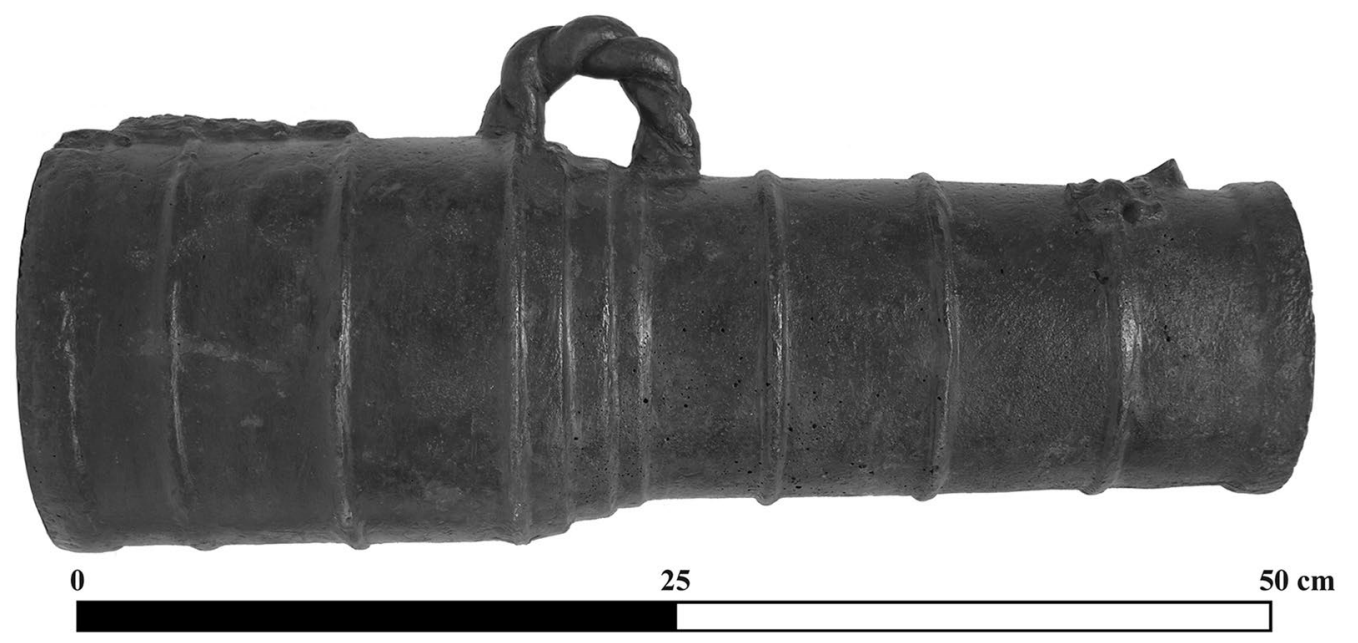

Fig. 7 Light field cannon from Kurzętnik. G. Żabiński

chamber's diameter is $5.0 \mathrm{~cm}$. This gun is mounted on a two-wheel carriage, provided with an "aiming bracket" or a split-trail elevation ([4], p. 310-311, No. 25).

An interesting iron-forged field cannon is stored in the Museum in Nový Bydžov in the Czech Republic (barrel length $53.5 \mathrm{~cm}$, calibre $11 \mathrm{~cm}$, powder chamber diameter $7.0 \mathrm{~cm}$ ). The chase of this gun is also wider than the breech, although not as much wider as in the case of the Grodno gun. The Nový Bydžov cannon is dated to the 1st quarter of the 15th c. ([2], p. 85, 88-89, 366, Pl. 86, cat. No. 71; [40], p. 36; for other similar cannons see ([2], p. 89; [41], p. 91-92, Figs. 2-3).

Yet another relevant find is a copper alloy field cannon from the fortress of Belgrade in Serbia. Its total length is $84 \mathrm{~cm}$, the breech length is $40 \mathrm{~cm}$ and the calibre is $13 \mathrm{~cm}$. The chase is somewhat wider than the breech. This gun can possibly be dated to the 1st half of the 15th c. and its deposition may be related to the Turkish sieges of Belgrade in 1440 or in 1456 ([2], p. 87-88, Fig. 11; [42], p. 20).

Similar guns are often depicted in late medieval and early modern period manuscripts. A good example of a light cannon on a wheeled carriage provided with an "aiming bracket" can be seen in the Anleitung, Schiesspulver zu bereiten Büchsen zu laden und $z u$ beschiessen from the early 15th c. (Fig. 8(1)). A similar example is displayed in Das Buch von der Büchsenmeisterei, dated to the $1460 \mathrm{~s}$ (Fig. 8(2)). The same manuscript features yet another gun of this kind, mounted on a much more complex wheeled carriage (Fig. 8(3)). Analogous light cannons can also be seen in the München copy of Maximilian I's Zeugbuch from the beginning of the 16th c. (Figs. 8(4-5)).

\section{Technology of early copper alloy firearms}

Barrels of early firearms in Europe were made either of iron and steel, or of copper and its alloys ([1], p. 11-19; [2], p. 105-106, 214-238; [10, 11]; [46], p. 33-34). Strzyż says that in the case of smaller copper alloy cannon barrels the lost-wax or cire-perdue technique may have been applied. A core was first prepared using a wooden shaft, wrapped with ropes and covered with clay. The surface of the core was then covered with tallow and wax. Next, a clay mould was formed around the core. The mould was then fired and the wax was melted away through openings in the mould ([2], p. 225-226). In the end of the first half of the 15th c. a new technology on the basis of wooden models was introduced. It allowed for the serial production of barrels of hand-held firearms ([2], p. 225-227).

The process of casting a large Turkish cannon's breech during the siege of Constantinople in 1453 was described by Kritoboulos in 1467. First, a cylindrical core was prepared using clay and linen. Then, a clay and linen mould was made and it was additionally strengthened using timber, wood, stones and earth. The core was placed inside the mould in such a manner that empty space for the cast metal was left (Kritoboulos' account after ([47], p. 186-187).

The issue of cannon barrel casting was discussed in great detail by a Sienese metallurgist Vannoccio Biringuccio in the first half of the 16th c. First, a pattern exactly reproducing the shape of the gun is prepared on a wooden beam, wrapped around with a rope and covered with clay and ash. Then, a feeding head which will be placed at the mouth of the gun is made. Next, two clay or wooden discs are prepared. These will be placed at both ends of the model and will accommodate both ends of an 

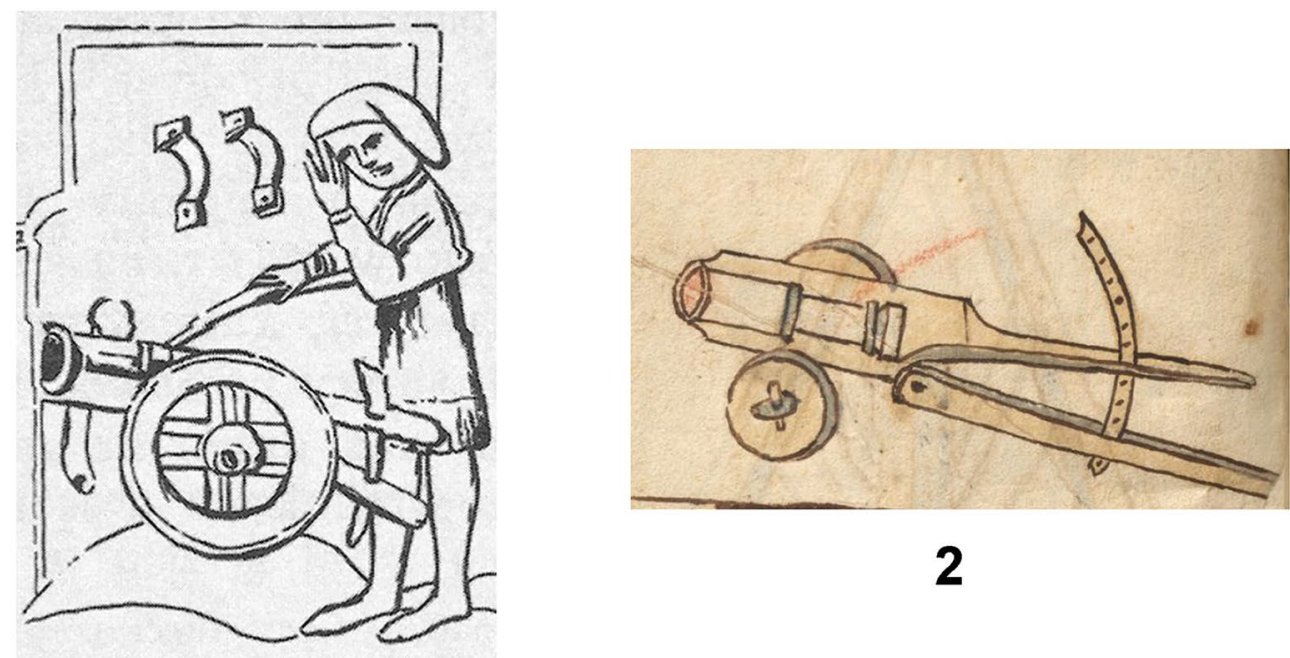

2

\section{1}

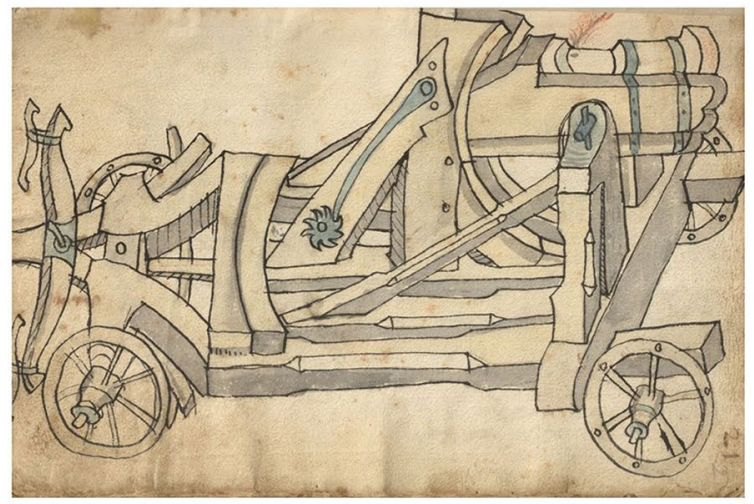

3

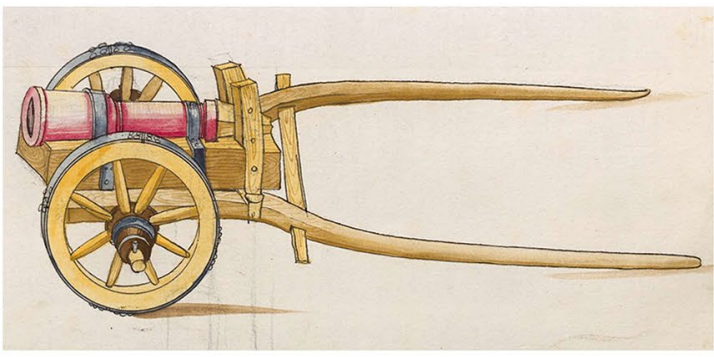

4

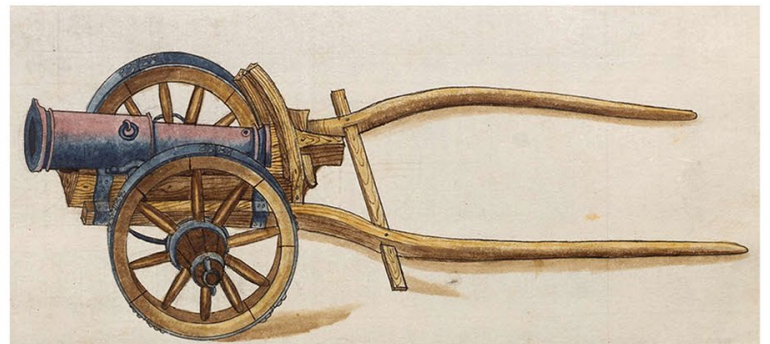

5

Fig. 8 Light field cannons in late medieval and early modern period manuscripts—selected examples: 1 [43]. Copyright Bayerische Staatsbibliothek München; 2 ([44], p. 32v). Copyright Germanisches Nationalmuseum Nürnberg; 3 ([44], p. 21r). Copyright Germanisches Nationalmuseum Nürnberg; 4 ([45], p. 187v). Copyright Bayerische Staatsbibliothek München; 5 ([45], p. 188v). Copyright Bayerische Staatsbibliothek München 
iron core. Trunnions are fastened to the pattern, and they are covered with ash and tallow. Then, the mould is made of layers of loam, reinforced with an iron "cage", and covered with another layer of clay. The mould is dried and heated and when the wax and tallow between the pattern and the mould are melted, the pattern is removed. An iron ring with four legs is then placed at the end of the mould in order to hold the core in its centre. The core is made from an iron spindle covered with ash, ropes, hemp tow and a mixture of various components. It is then layered with clay and dung until the core's thickness roughly matches the projectile's diameter. The breech's mould is prepared analogously to the barrel's mould ([48], p. 234-249). The mould with the core inside (see Fig. 9) is vertically placed in a pit in front of the furnace ([48], p. 249-260). Concerning the alloy composition, a usual proportion for bronze is $8-12 \mathrm{lb}$ of tin per $100 \mathrm{lb}$ of copper (i.e., $7.4-10.7 \% \mathrm{Sn}$ and $89.3-92.6 \% \mathrm{Cu}$ ) while the best recipe for bells' metal is $23-26 \mathrm{lb}$ of tin (i.e., $18.7-20.6 \% \mathrm{Sn}$ and $79.4-81.3 \% \mathrm{Cu}$ ). For "all other works" the content of tin is $12 \mathrm{lb}$ (i.e., $10.7 \% \mathrm{Sn}$ ) or more ([48], p. 210-211). In the course of casting attention must be paid to the melting loss of material (5-10\%) ([48], p. 266). Some tin should be added at the end of the process to make sure that the alloy will be of proper fluidity and will be devoid of holes ([48], p. 259-260). Eventually, the gun is extracted from the pit, the mould and the core are removed and finishing work is carried out ([48], p. 307-312).

Numerous fragments of clay and metal moulds for casting cannons, lumps of clay and copper alloy, and remains of casting installations were discovered in the Teutonic Order's capital Castle of Marienburg (Malbork) at the site of a former foundry $[49,50]$. Written records from the Teutonic Order's state in Prussia contain numerous references to gun casting ([9], p. 99-101). Remains of a

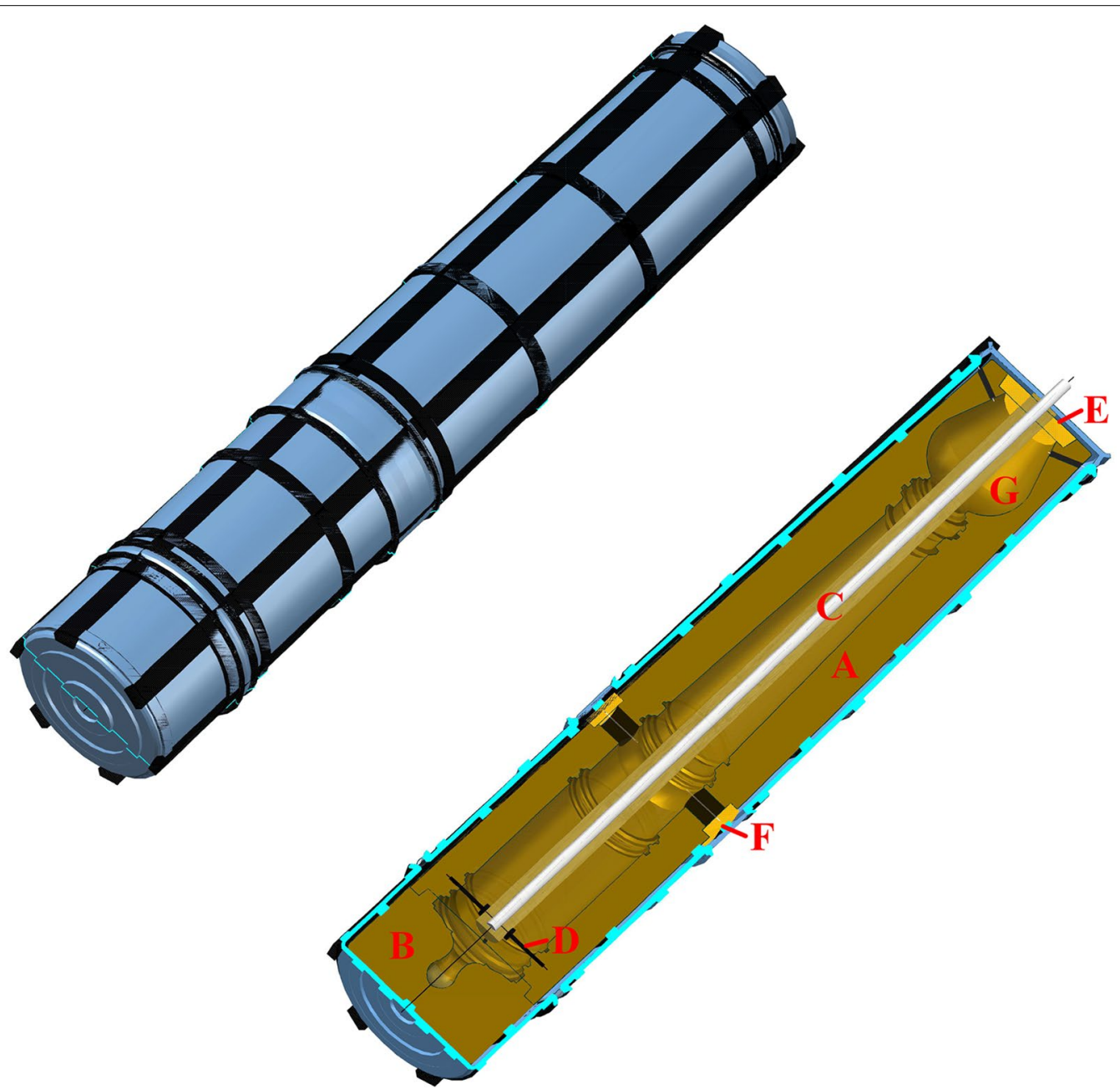

Fig. 9 A reconstruction of the gun mould. After ([9], p. 98, Fig. 1). A Main body mould; B breech mould; C core; $\mathbf{D}$ iron chaplets holding the core; $\mathbf{E}$ clay disc holding the core; $\mathbf{F}$ bricks closing the trunnion cavities; $\mathbf{G}$ feeding head 
gun foundry from the late 15th-early 16th c. were also recorded in the course of excavations at the castle hill in Buda in Hungary [51].

In Central Europe, numerous examples of hand-held firearms from the period between the late 14th and the 3 rd quarter of the 15th c. were made of copper alloys ([2], p. 30-34, 36, 37, 39-41). Mentions in written sources suggest that in this period there was (at least locally) a preponderance of copper and copper alloy hackbuts over iron ones. This fact is in contrast to the proportion of surviving artefacts, where iron guns prevail. This can be explained with widespread recycling of outdated or damaged copper alloy barrels ([2], p. 47-51; [23], p. 100; see also [52], p. 113-121]). Copper alloy barrels can also be found in hand-held firearms in the 2nd half of the 15thearly 16th c. ([2], p. 55, 56, 63, 64). A preponderance of copper alloy hand-held firearms in the first half of the 15th c. has also been suggested for other parts of Europe ([53], p. 68-71, 301-304), but this was not necessarily a universal rule ([4], p. 217; [53], p. 316, 454, 555-556).

Among the surviving specimens of so-called terraceguns (a type of light cannons) in Central Europe, there is an almost total absence of copper alloy barrels. This may also be due to mass recycling of old guns, as written sources from the first half of the 15th c. mention copper or bronze barrels much more frequently than iron ones ([2], p. 78, 80-81). Examples of both iron and copper or copper alloy light field cannons are known, and copper guns of this kind are mentioned in written sources ([2], p. 85-92). Among veuglaires there is a preponderance of iron barrels, although copper and copper alloy ones are known from written records, too ([2], p. 93-101). In the case of the largest cannons, iron and a stave-and-hoop construction were preferred in Europe, but huge bronze cannons are also known both from surviving artefacts and from written sources ([1], p. 20; [2], p. 104-106, 108$109,232-233$; [4], p. 204, 262-267; [7, 8], [40], p. 79-80, Tabs. 1-2). In general, it can be assumed that in the period to the mid-15th c. copper alloy guns were more popular than iron ones ([2], p. 213-214). In the Italian Peninsula, iron cannons were still in use in the late 15thearly 16th c., but the significance of bronze ordnances (especially the largest ones) was constantly increasing ([54], p. 756-770, Table 1). Copper cannons in castles and towns in the south-eastern part of the Habsburg realm (present-day Slovenia) are sometimes mentioned in the afore-mentioned München copy of Maximilian's Zeugbuch from the early 16th c. ([55], p. 66, 67).

The Teutonic Order was one of the parties involved in fights over the Old Castle in Grodno. Therefore, it is worth paying attention to abundant data in written sources concerning the technology of manufacture of copper alloy firearms in the Order's state in Prussia. Regrettably, nothing comparable is available for Poland or Lithuania. Mentions of copper guns in the Order's accounts and inventories are not frequent. On the other hand, it is evident that a difference between copper and bronze guns was known to the authors of these records, as they make a distinction between kopperyne/kopperen (copper) and erynne/eren (bronze) firearms. Copper firearms in the Teutonic Order's state were either hand-held guns or lighter cannons ([9], p. 86-88).

Concerning a general pattern of use of metals for gun barrels in the Teutonic Order's state in the period between the late 14th and the early 16th c., there was a preponderance of copper and copper alloy guns over iron ones. 385 guns were recorded in written sources, and more than $65 \%$ of these were made using copper and its alloys, copper guns being more than $17 \%$ ([9], p. 84-88, Table 1).

A preponderance of copper alloys is even more visible in manufacture and purchase of new firearms, although it must be remembered that the lion's share of this data comes from a narrow period of the early 15th c. Among 103 acquired guns, almost $80 \%$ were made using copper and its alloys, the share of copper guns being about $6.8 \%$. A dominance of copper alloys is even more pronounced in the case of artillery $(92.7 \%$ cases) and almost all the largest guns acquired by the Order were made of bronze. This alloy must have been considered the best material for the heaviest cannons, in spite of the fact that bronze was more expensive than iron. This implies that more attention was paid by the Order's authorities to quality than to economic costs ([9], p. 87-92, Table 2); on quality issues of bronze and iron artillery see also, e.g., ([54], p. 756-757).

The Teutonic Order's guns cast at Marienburg (Malbork) in 1401 were manufactured of almost pure copper (about $97-97.5 \% \mathrm{Cu}$ ). A rather low amount of tin (about 2.5-3\% Sn) did not have much influence on their utilitarian properties. This low content of Sn may have been related both to the use of recycled metal or to Sn impurities in particular copper ores. Provided that these guns were of more or less equal weight, they were probably rather small ordnances (about $120 \mathrm{~kg}$ each). Therefore, their manufacturers may have assumed that such a composition would suffice to provide these guns with proper toughness. In two veuglaires from 1403, the proportion of tin was much higher (almost $11 \% \mathrm{Sn}$ ) and these ordnances may have been smaller than the guns from 1401. The total weight of one cannon with three powder chambers was perhaps a bit more than $100 \mathrm{~kg}$, that is, about $70-76 \mathrm{~kg}$ for the chase with one chamber. It could be assumed that these veuglaires were manufactured using tougher and harder metal as they were 
exposed to stronger wear in result of a higher rate of fire ([9], p. 101-103; [23], p. 107].

The chemical composition of the three largest Teutonic cannons varies. Regarding the largest ordnance, that is, the Grose Bochse, the content of tin is nearly 13\% Sn, which may suggest extra toughness. The amount of tin was even higher (nearly $17.5 \% \mathrm{Sn}$ ) in the case of the Bochse nest der grosen. On the other hand, worth noting is the share of lead $(0.85 \% \mathrm{~Pb})$ in the metal of the Grose Bochse. It was added when the chase of the ordnance was cast again. As regards the Lange Bochse from 1409, its tin content (more than $5.5 \% \mathrm{Sn}$ ) is more similar to that in the smaller cannons than in the largest ordnances ([9], p. 103; [22], p. 56, 58-60; [46], p. 32-33, Table 1).

\section{Technological examinations of the cannon from Grodno \\ Methods}

Four samples were analysed-three of these (Samples 1-3) came from the loose parts of the chase found with the cannon, while Sample 4 was taken from the front edge of the chase part within the gun's main body (see Fig. 3). The samples were mounted in Electro-Mix electroconductive resin, ground on $\mathrm{SiC}$ papers $(500,800$, 1000, 1200, and 2000 grits) and polished with diamond pastes $(6,1$ and $0.5 \mu \mathrm{m})$. Next, they were etched with a Mi17Cu reagent $\left(10 \mathrm{~g} \mathrm{FeCl}_{3}, 30 \mathrm{ml} \mathrm{HCl}, 120 \mathrm{ml} \mathrm{C}_{2} \mathrm{H}_{5} \mathrm{OH}\right)$ for $2 \mathrm{~s}$ in order to reveal the microstructure. Metallographic observations (for Samples 1 and 4 only) were carried out with an OptaTech MM100 inverted metallographic microscope (magnifications $\times 50-\times 200$; bright field) coupled with a $16 \mathrm{mpx}$ digital camera. Chemical composition analyses of all samples were carried out with a JEOL JSM-6480 scanning microscope operating at $20 \mathrm{kV}$ and equipped with an IXRF $\mathrm{Si}(\mathrm{Li}) \mathrm{LN}_{2}$ EDS-type detector. The equipment was energy calibrated using an $\mathrm{Al}-\mathrm{Cu}$ reference sample by Agar Scientific. The measurement time was $50 \mathrm{~s}$ per point and quantitative analyses were done using the standard-less method with the ZAF correction. The detection limit was $0.1 \mathrm{wt} \%$, and the measurement error was $<10 \%$ for major elements (above $1.0 \mathrm{wt} \%$ ) and $<30 \%$ for minor elements (below $1.0 \mathrm{wt} \%$ ). Results are averages of several measurements over the whole surface of each sample (see Table 1). While discussing the results of the technological analyses it must be remembered that the artefact was found in a firerelated archaeological layer. Thus, a prolonged exposure to heat may have influenced the cannon's microstructure.

\section{Results and discussion}

Microscopic observations have revealed the presence of high pore density in the metal of the cannon (an effect of gases remaining in the liquid in the course of solidification), especially in Sample 4 from the chase (Figs. 10b, c, 11a, b, 12a, b, d, f, and 13a, b). The pores are regular in shape, which may indicate that they were formed while the liquid metal was poured into the mould and were trapped by crystallisation processes. Such undesirable structures in the metal could actually have an adverse effect on the mechanical properties of the material [47]. Interestingly, considerable porosity of the microstructure was also found out in the metal of the Teutonic light cannon from Kurzętnik (Kauernick) ([20], p. 182, Fig. 37, p. 186]. This may indicate that late medieval metalworkers assumed that this defect would not pose a problem with the use of guns (on porosity that frequently occurs in large castings see also ([47], p. 192; [56], p. 88]). The method of casting of the artefact also influenced the shape and size of grains. These are usually equiaxial and their sizes strongly vary. In most cases these are 100$200 \mu \mathrm{m}$ in diameter, but larger grains of up to $500 \mu \mathrm{m}$ were observed as well (Figs. 10b, d, f, 11a, b, 12b, d, f, and 13a, b). Usually, grains in archaeological copper alloys are smaller, values below $50 \mu \mathrm{m}$ being the most frequent ([56], p. 59, Fig. 3.38). There are no grain elongations and the grain shape is usually regular, which indicates that the metal did not undergo any cold-working after casting (cf. [57], p. 42-44). No dendritic structures which remain in as-cast metals $([56]$, p. $58,59,83)$ can be seen. Repeated annealing usually removes such structures ([5], p. 93-94; [56], p. 100-101), but such a procedure would be unlikely in gun manufacture. Therefore, the absence of dendrites is to be attributed to the casting process itself and to a rather slow cooling rate (maybe in a pre-heated mould?), which may also be indicated by the large grain size ([5], p. 94; [47], p. 193, 197, 201, 204; [56], p. 59, 83, 155). No dendritic structures were reported in the metal of the Kurzętnik (Kauernick) cannon, either ([20], p. 182, Fig. 37).

Inclusions were found in some places in the $\mathrm{Cu}$ alloy matrix (Figs. 10e, 11b, and 12c, e, f). The EDS examinations demonstrated that the inclusions in the metal gun mainly contained $\mathrm{Cu}, \mathrm{S}, \mathrm{Pb}, \mathrm{Sn}$ and $\mathrm{Fe}$ (see Table 1). Thus, they may be copper sulphides. Sulphide inclusions $\left(\mathrm{Cu}_{2} \mathrm{~S}\right.$ or others) can frequently be found in archaeological copper alloys and their presence is usually related to the use of sulphide-rich ores ([56], p. 3, 10, 11, 13, 34, 35, Figs. 3.14-3.15, p. 44, Fig. 3.25, p. 56, Fig. 3.34, p. 87, Fig. 4.20, p. 89, Fig. 4.22, p. 94, 139; [58]). Most interestingly, copper sulphides were also identified in the metal of the Kurzętnik (Kauernick) cannon ([20], p. 184, 186, Fig. 38c, d), which might also imply that the metal was smelted of such ores.

The EDS examinations demonstrated that the cannon from Grodno had been cast using leaded copper (Table 1). The average value of $\mathrm{Cu}$ is $90.96 \%$, the $\mathrm{Sn}$ 

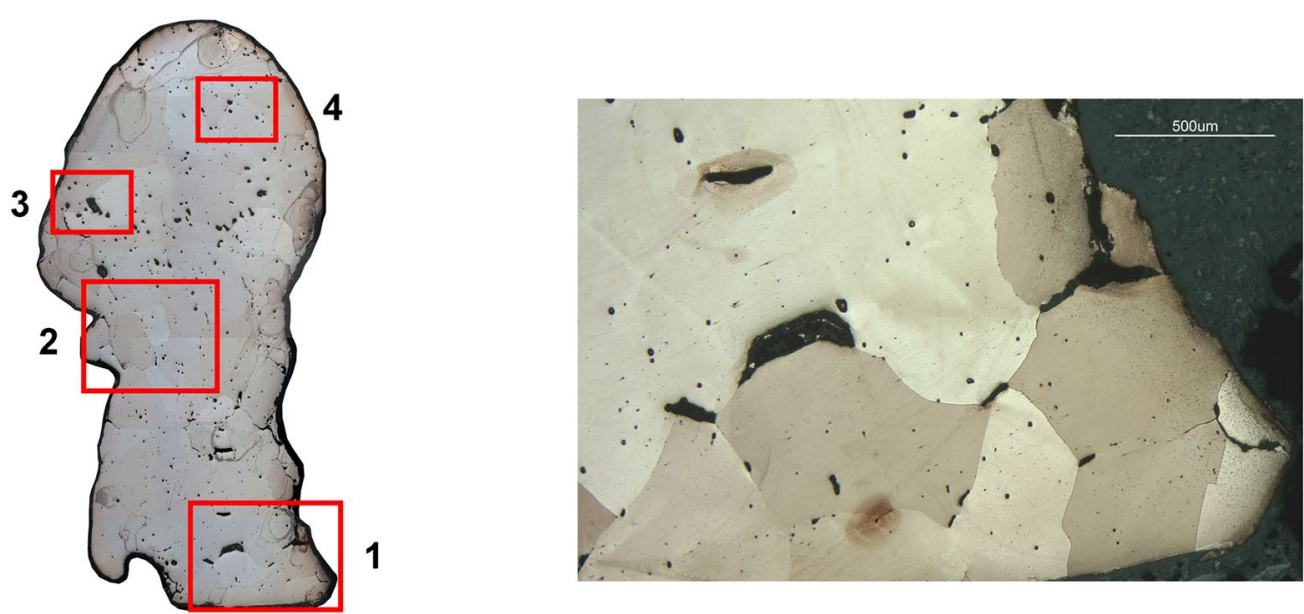

0

\section{$5 \mathrm{~mm}$}

a

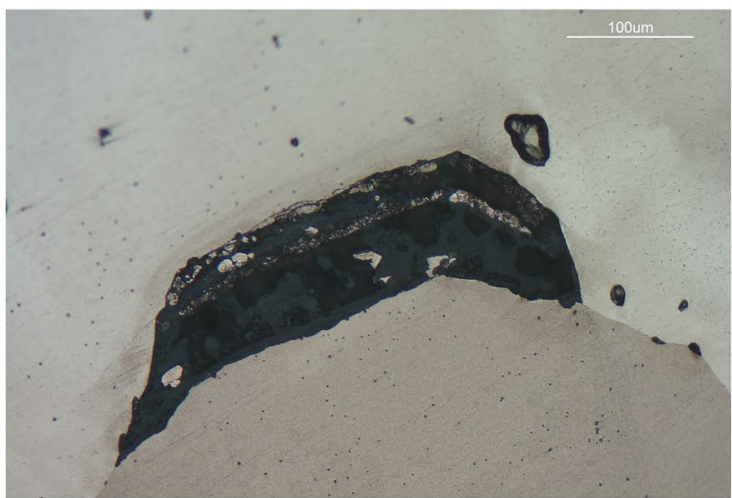

C

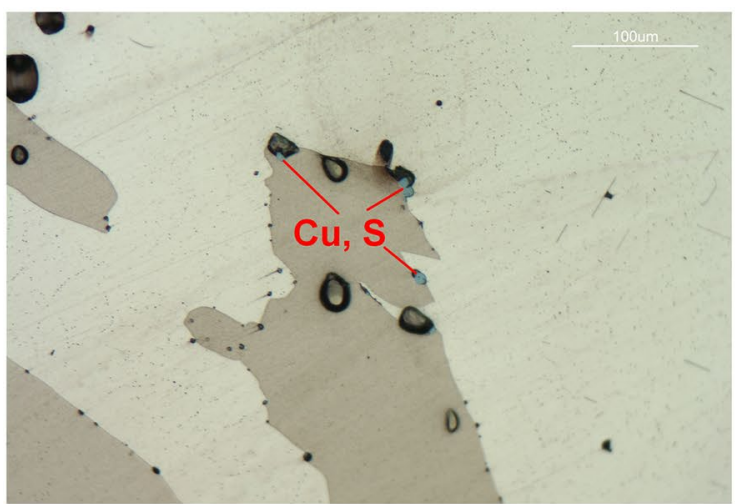

e b

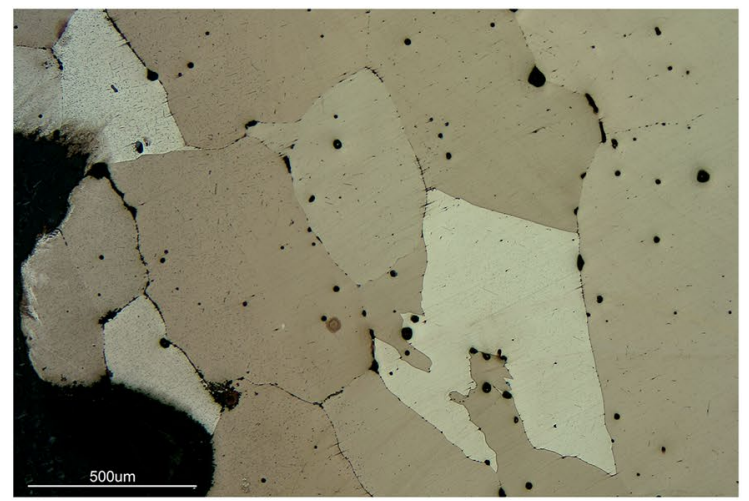

d

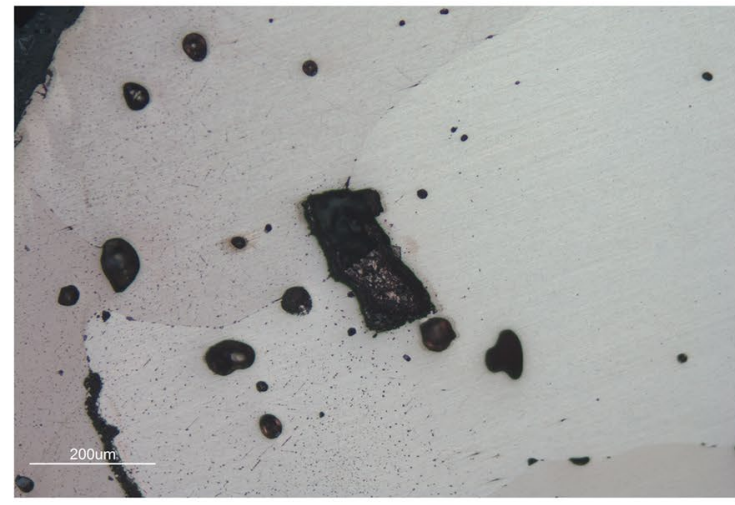

f

Fig. 10 Cannon from the Old Castle in Grodno, Sample 1-results of metallographic examinations. a general view of the sample with zones of detailed observations (1-4). b, c microstructure in Zone 1, pores of various size and shape. d, e microstructure in Zone 2, CuS inclusions (light blue) in the Cu-Pb matrix. f microstructure in Zone 3, numerous pores 


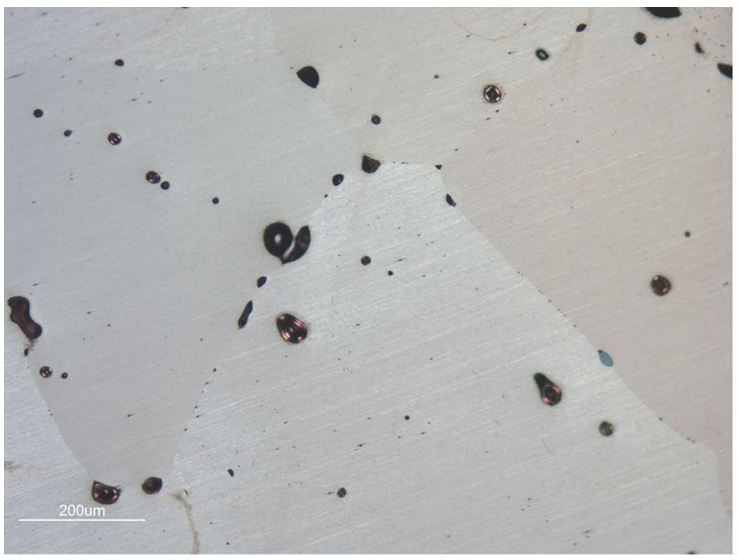

a

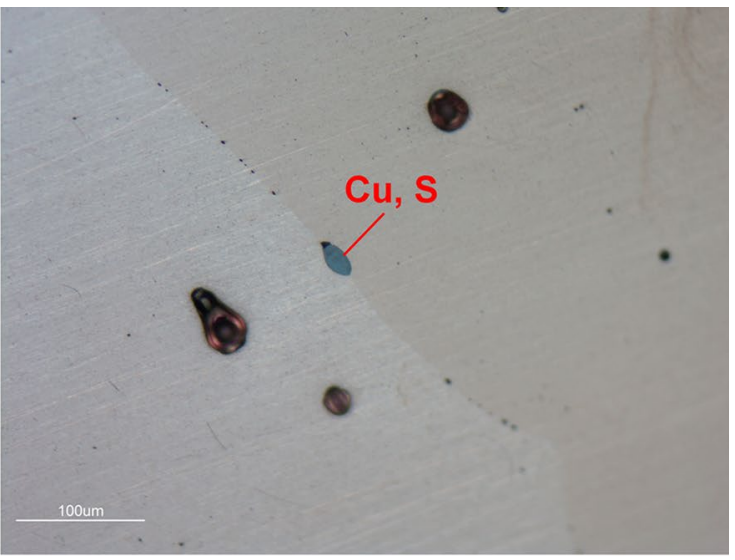

b

Fig. 11 Cannon from the Old Castle in Grodno, Sample 1-results of metallographic examinations. a, b microstructure in Zone 4, numerous pores and an isolated CuS inclusion (light blue) in the $\mathrm{Cu}-\mathrm{Pb}$ matrix

content is $1.01 \%$, while the content of $\mathrm{Pb}$ is $3.77 \%$. This implies that lead may have been deliberately added to improve the alloy's casting properties (cf. [5], p. 94); on leaded copper see also ([56], p. 153-154). The content of $\mathrm{Sn}(1.01 \%)$ is too low to have any practical influence on the alloy's properties. The amount of $\mathrm{Sb}(0.76 \%)$ may have somewhat increased the metal's toughness, but its low content indicates that Sb was impurity ([56], p. 137, 139-143) and not intentional additive to the alloy. Yet another likely impurity is $\mathrm{Ag}(0.76 \%)$. All these elements may either be related to the ore of which the metal was smelted, or their presence may be a result of the use of recycled metal, possibly from multiple sources.

In order to trace possible technological similarities between the Grodno cannon and other copper alloy guns, these results can be compared with observations concerning the elemental composition of other firearms. The number of medieval and modern period copper alloy guns which underwent technological examinations focusing on the elemental composition of their barrels is far from satisfactory. However, a short list of results was prepared on the basis of available literature (including data from late medieval written sources). Concerning written sources, for obvious reasons a prominent place is held by records related to the Teutonic Order. It must naturally be remembered that individual cases are not always fully comparable due to different analytical methods (in most cases, these guns were examined with the XRF method), equipment, research procedures (especially sampling strategies), and so on. Furthermore, late medieval written sources offer rather estimates than exact figures and these obviously contain data on a few major elements only. Nevertheless, some interesting hypotheses can be proposed (see Additional file 1: Sheet 1, all data in wt\%).
The first important observation is that although later guns (i.e., those dated to the second half of the 15th c. or later) were usually made of copper alloys with less than c. $95 \% \mathrm{Cu}$ and more than c. $5 \%$ Sn or other alloy components, there are also artefacts whose alloy contains a higher amount of $\mathrm{Cu}$. Such firearms could perhaps be termed "copper guns" by people of those days. The use of alloy with c. $95 \% \mathrm{Cu}$ or more seems to have been limited to hand-held firearms and lighter guns, a $9100 \mathrm{~kg}$ heavy Swiss cannon from 1409 being a notable exception. Regarding the heaviest cannons, most of these were cast using bronze containing at least $\mathrm{c}$. $10 \% \mathrm{Sn}$, which seems to match toughness requirements that were expected in the case of such ordnances. The tensile strength of pure copper is about $35 \mathrm{mkg} / \mathrm{cm}^{2}$, and increases up to c. $50 \mathrm{mkg} / \mathrm{cm}^{2}$ when the $\mathrm{Sn}$ content is about $5 \%$. The strength of tin bronze reaches its maximum value of c. $70 \mathrm{mkg} / \mathrm{cm}^{2}$ for the $S n$ content of about $13 \%$. Above this value, the tensile strength gradually decreases to over $20 \mathrm{mkg} / \mathrm{cm}^{2}$, when the Sn content reaches $25 \%$ ([56], p. 149 , Fig. 5.16). It is therefore obvious that the share of c. $10-13 \%$ of Sn was the most proper for the largest cannons, which were exposed to the heaviest stress in the course of their use. Attention is also drawn to the share of $\mathrm{Pb}$, which may even reach more than $15 \%$. This may be a result of compositional differences between various parts of a given gun. In the case of some 16th c. cannons from a Venetian shipwreck found near Sv Pavao in Mjlet Island (Croatia), the amount of lead was the lowest in the muzzle and the highest in the breech. What is more, these differences may also be due to sampling procedures ([6], p. 157; [56], p. 83). Samples were taken from surface layers, and as the temperature of solidification of $\mathrm{Pb}$ is 

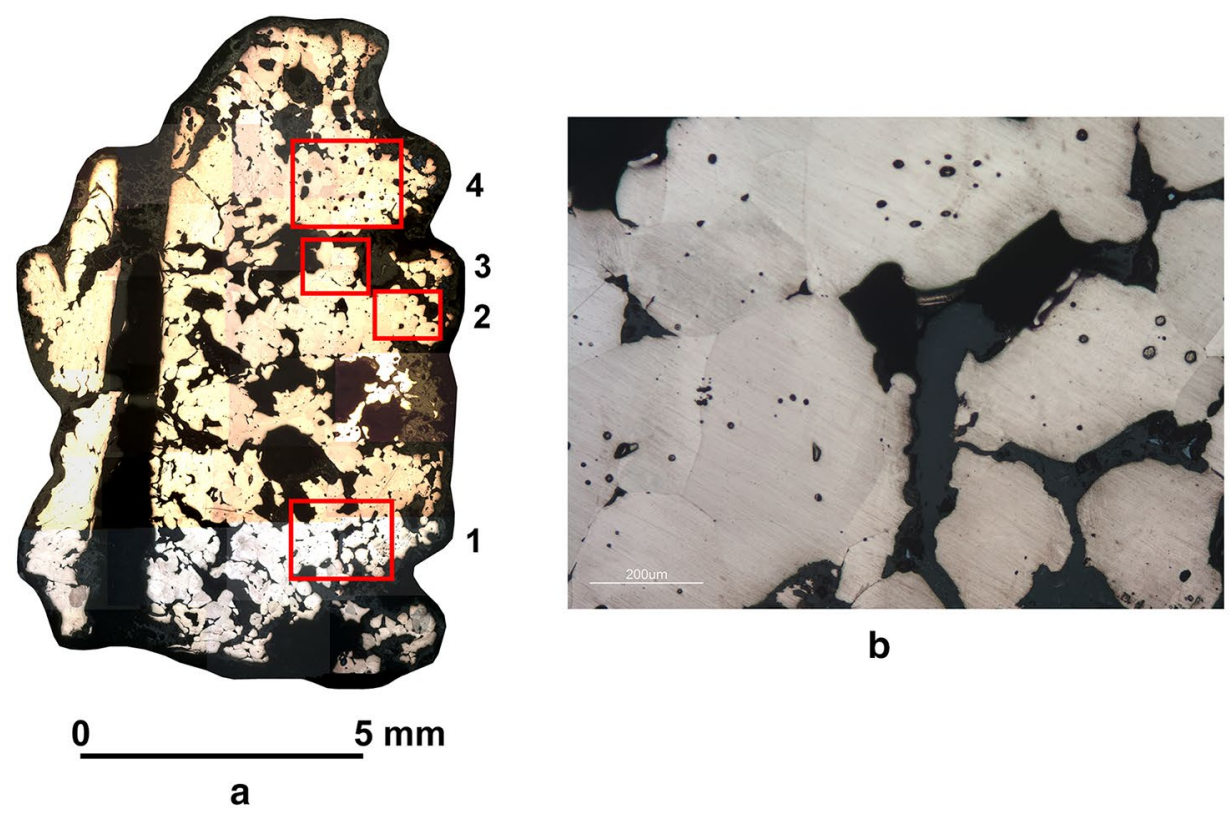

b
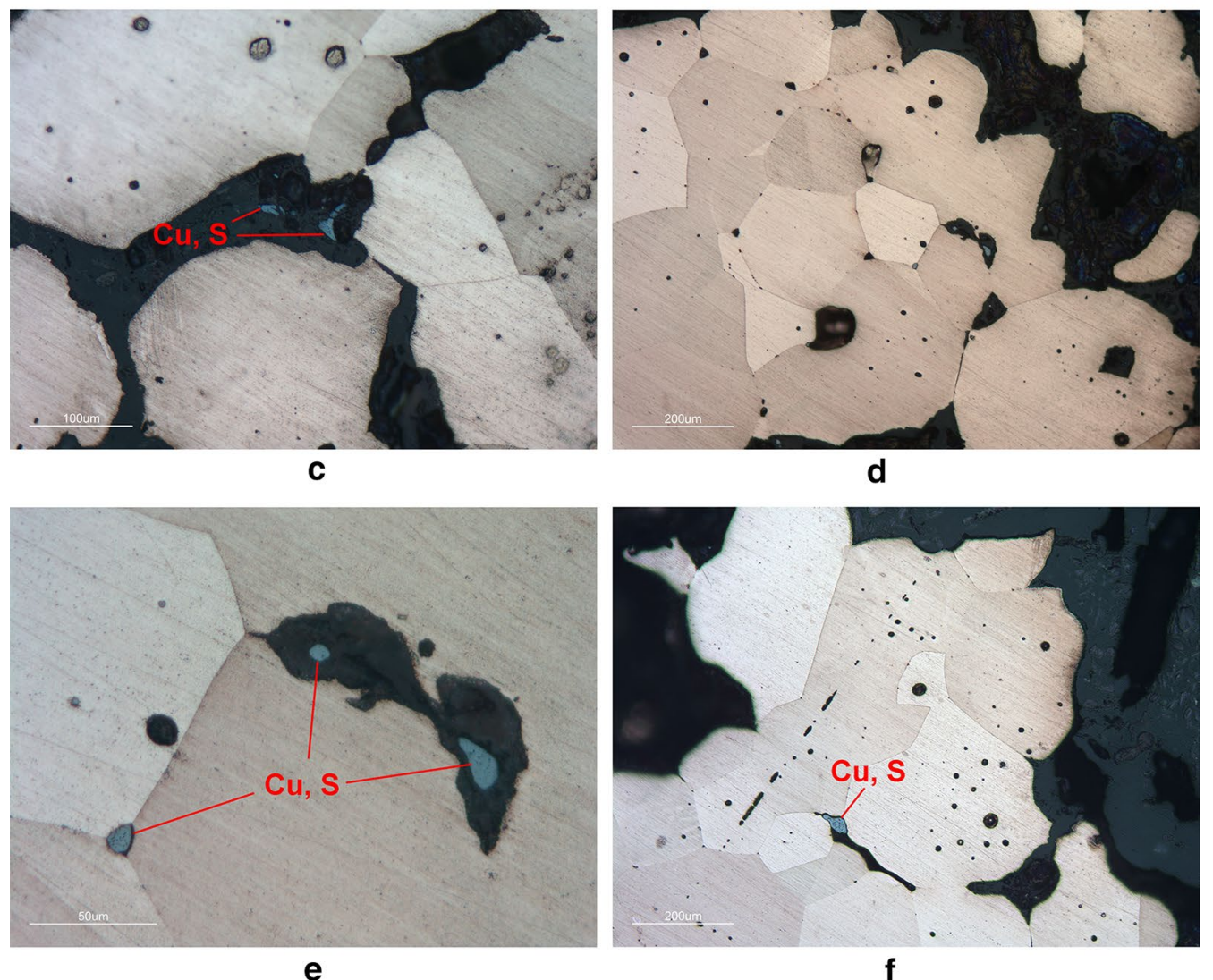

Fig. 12 Cannon from the Old Castle in Grodno, Sample 4-results of metallographic examinations. a general view of the sample with zones of detailed observations (1-4). b, c microstructure in Zone 1, pores of various size and shape, sometimes with CuS inclusions (light blue). $\mathbf{d}$, e microstructure in Zone 2, pores of various size and shape, sometimes with CuS inclusions (light blue). $\mathbf{f}$ microstructure in Zone 3, pores and a CuS inclusion (light blue) 


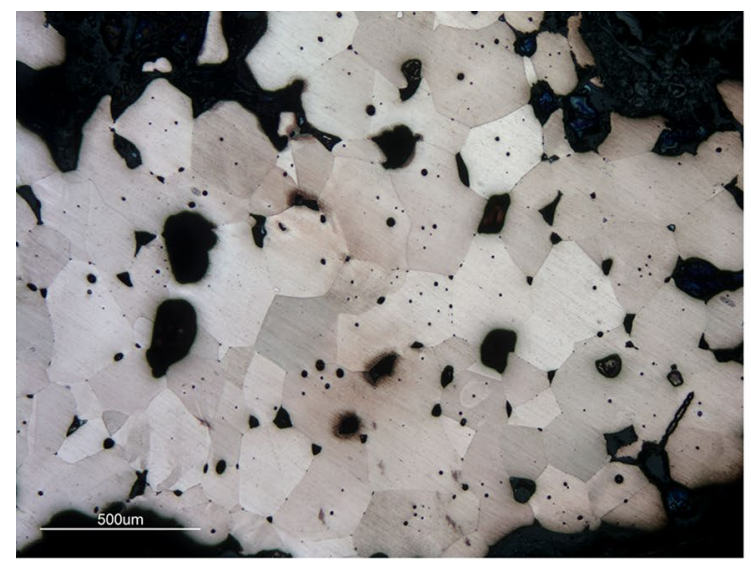

a

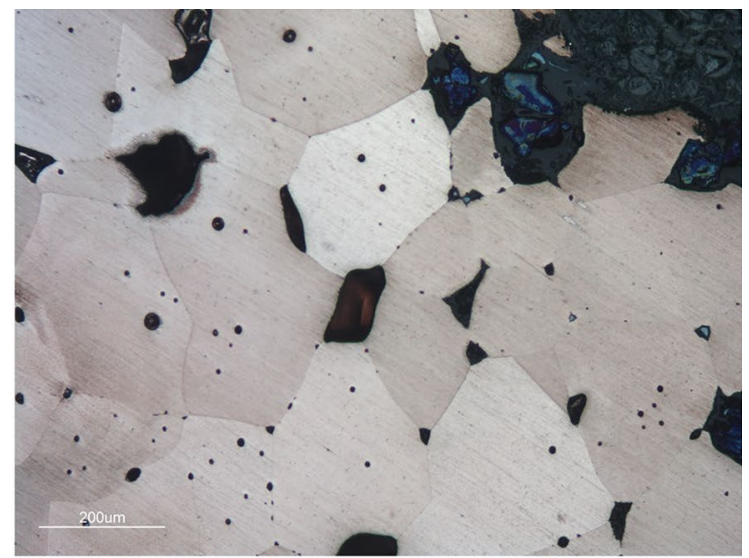

b

Fig. 13 Cannon from the Old Castle in Grodno, Sample 4-results of metallographic examinations. a, b Microstructure in Zone 4, numerous pores

lower than that of $\mathrm{Cu}$ and $\mathrm{Sn}, \mathrm{Pb}$ tends to migrate to the surface. Thus, the results obtained on the basis of samples taken near the surface are not representative for the chemical composition of entire artefacts ([59], p. 57]). A similar observation concerning the varying amount of $\mathrm{Sn}$ in the alloy due to different solidification temperatures of $\mathrm{Cu}$ and $\mathrm{Sn}$ was stated by Morin for two $16^{\text {th }}$ Venice cannons $([60]$, p. 10$)$. It is of interest that a considerable amount of $\mathrm{Pb}$ can be found both in handheld firearms as well as in cannons. Lead may have been added to secure better casting properties and elasticity ([5], p. 94, 101-102; [61], p. 3063-3064), but the actual effect of a too high content of $\mathrm{Pb}$ on the gun's performance may have in fact been the opposite ([9], p. 103).

There are other guns where the contents of $\mathrm{Cu}$ (about 90\%) and Sn (about 1-2\%) are similar to those in the Grodno gun (Additional file 1, Sheet 1, Nos. 10-11, $32-33,55-56$ ), but the content of $\mathrm{Pb}$ was usually different (either below $1 \%$ or above $6 \%$ ). Concerning guns where the $\mathrm{Pb}$ content was similar (i.e., about $3-5 \%$ ) to that in the Grodno cannon, it was usually accompanied with a higher content of Sn (above 5\%, sometimes even 8-9\%) (Additional file 1, Sheet 1, Nos. 35, 47-50, 65), which certainly influenced the alloy's properties. Only in the case of a 15th c. hand-held gun from Valečov in Bohemia the contents of $\mathrm{Cu}, \mathrm{Pb}$ and $\mathrm{Sn}$ were close to those in the Grodno cannon (Additional file 1, Sheet 1, No. $11-93.03 \% \mathrm{Cu}, 4.32 \% \mathrm{~Pb}$ and $1.04 \% \mathrm{Sn}$ ). Similarities were also found concerning the front sample from Cannon 3 from the 16th c. shipwreck in Sv Pavao, Croatia (Additional file 1, Sheet 1, No. 32-91.15\% Cu, $4.27 \% \mathrm{~Pb}$, and $1.21 \% \mathrm{Sn}$ ), but this is obviously not representative for the entire gun (Additional file 1, Sheet 1 , Nos. 32-34 and their average chemistry).
In order to better visualise possible technological similarities, results were normalised to $100 \%$ and were displayed on a $\mathrm{Cu}-\mathrm{Pb}-\mathrm{Sn}$ ternary graph (Fig. 14) (see also bivariate scatterplots of $\mathrm{Cu}-\mathrm{Sn}, \mathrm{Cu}-\mathrm{Pb}$, and $\mathrm{Pb}-\mathrm{Sn}$, Additional file 1, Sheets 3-4). Observations where variables were missing were discarded. For the sake of a better representativeness, data from individual samples and not averages for the entire guns were used. All operations were carried out in XLSTAT, Ver. 2021.1.1. The aforementioned similarity between the Grodno cannon, the hand-held gun from Valečov and the front part of Cannon 3 from Sv Pavao is evident. With regard to a high amount of $\mathrm{Cu}$ and a low amount of $\mathrm{Sn}$ (3\% or less), attention is also drawn to a late 14th c. bolt gun from Loshult in Sweden, a mid-15th c. hand-held gun from Wenecja in Greater Poland, two mid-15th c. hand-held guns from Mstěnice in Moravia, and a 16th c. swivel gun from Benin in Nigeria. It is worth noting that all these are either hand-held firearms or light cannons. Therefore, in the case of the Grodno gun the contents of elements which were the most crucial from a utilitarian point of view is not uncommon for light firearms. The choice of alloy for the Grodno gun may have been meant to facilitate the manufacturing process, as no extra toughness was needed in such a light field cannon.

\section{Possible provenance of the Grodno gun}

Provenance of an archaeological find understood as the place or region where it was made and provenance of its raw material are in many cases two different things. This is especially true for copper alloy artefacts, as copper ores are by far not as frequent as, e.g., iron ores. Regarding the place of manufacture of the Grodno gun, the archaeological and historical evidence could equally suggest a 
Table 1 Elemental composition of the cannon from Grodno (wt\%)

\begin{tabular}{|c|c|c|c|c|c|c|c|c|c|c|c|c|c|c|c|c|}
\hline & $\mathrm{Cu}$ & $\mathrm{Pb}$ & Sn & Al & $\mathrm{Si}$ & $S$ & $\mathrm{Ti}$ & $\mathrm{Cr}$ & $\mathrm{Mn}$ & $\mathrm{Fe}$ & $\mathrm{Ni}$ & $\mathrm{Zn}$ & As & $\mathrm{Ag}$ & $\mathrm{Sb}$ & Total \\
\hline \multicolumn{17}{|c|}{ Sample 1 (Chase Part 1) } \\
\hline \multicolumn{17}{|l|}{ Zone 2 inclusions } \\
\hline Point 1 & 75.83 & 3.75 & 0.43 & 0.84 & 0.11 & 14.79 & 0.27 & 0.12 & 0.25 & 1.39 & 0.56 & 0.34 & 0.00 & 0.24 & 1.08 & 100.00 \\
\hline Point 2 & 79.90 & 3.73 & 0.78 & 0.56 & 0.00 & 12.30 & 0.19 & 0.36 & 0.16 & 0.29 & 0.40 & 0.29 & 0.00 & 0.52 & 0.52 & 100.00 \\
\hline Point 3 & 74.91 & 2.72 & 0.45 & 0.46 & 0.00 & 15.16 & 0.00 & 0.18 & 0.23 & 3.06 & 0.23 & 0.80 & 0.00 & 0.58 & 1.22 & 100.00 \\
\hline \multicolumn{17}{|l|}{ Zone 2 matrix } \\
\hline Point 4 & 92.99 & 3.18 & 0.65 & 0.13 & 0.10 & 0.22 & 0.18 & 0.21 & 0.17 & 0.25 & 0.32 & 0.40 & 0.13 & 0.54 & 0.53 & 100.00 \\
\hline \multicolumn{17}{|l|}{ Zone 4 inclusion } \\
\hline Point 5 & 73.34 & 4.86 & 0.40 & 0.84 & 0.00 & 17.35 & 0.21 & 0.40 & 0.10 & 0.58 & 0.56 & 0.29 & 0.30 & 0.00 & 0.78 & 100.00 \\
\hline \multicolumn{17}{|l|}{ Zone 4 matrix } \\
\hline Point 6 & 91.14 & 3.99 & 1.62 & 0.12 & 0.27 & 0.00 & 0.25 & 0.19 & 0.10 & 0.27 & 0.42 & 0.30 & 0.00 & 0.82 & 0.50 & 100.00 \\
\hline Area $9.375 \mathrm{~mm}^{2}$ & 90.40 & 5.30 & 0.73 & 0.00 & 0.40 & 0.00 & 0.33 & 0.20 & 0.23 & 0.18 & 0.40 & 0.36 & 0.00 & 0.84 & 0.62 & 100.00 \\
\hline Avg matrix & 91.51 & 4.16 & 1.00 & 0.08 & 0.26 & 0.07 & 0.25 & 0.20 & 0.17 & 0.23 & 0.38 & 0.35 & 0.04 & 0.73 & 0.55 & 100.00 \\
\hline SD matrix & 1.33 & 1.07 & 0.53 & 0.07 & 0.15 & 0.13 & 0.07 & 0.01 & 0.06 & 0.05 & 0.05 & 0.05 & 0.08 & 0.17 & 0.06 & \\
\hline \multicolumn{17}{|c|}{ Sample 2 (Chase Part 2) } \\
\hline \multicolumn{17}{|l|}{ Matrix } \\
\hline Point 1 & 91.57 & 4.71 & 0.33 & 0.15 & 0.29 & 0.10 & 0.25 & 0.22 & 0.26 & 0.21 & 0.27 & 0.49 & 0.00 & 0.44 & 0.71 & 100.00 \\
\hline Point 2 & 91.36 & 3.99 & 0.80 & 0.21 & 0.14 & 0.00 & 0.22 & 0.43 & 0.15 & 0.24 & 0.23 & 0.61 & 0.00 & 1.06 & 0.54 & 100.00 \\
\hline Point 3 & 92.16 & 3.55 & 1.05 & 0.34 & 0.00 & 0.00 & 0.15 & 0.19 & 0.18 & 0.26 & 0.00 & 0.43 & 0.00 & 0.33 & 1.37 & 100.00 \\
\hline Point 4 & 94.26 & 2.46 & 0.96 & 0.14 & 0.00 & 0.00 & 0.26 & 0.15 & 0.15 & 0.24 & 0.19 & 0.24 & 0.00 & 0.62 & 0.32 & 100.00 \\
\hline Point 5 & 90.13 & 5.19 & 0.49 & 0.00 & 0.24 & 0.00 & 0.30 & 0.37 & 0.13 & 0.26 & 0.18 & 0.72 & 0.00 & 1.04 & 0.94 & 100.00 \\
\hline Point 6 & 91.23 & 2.76 & 0.47 & 0.10 & 0.37 & 0.00 & 0.17 & 0.00 & 0.21 & 0.55 & 0.27 & 0.44 & 1.46 & 1.11 & 0.87 & 100.00 \\
\hline Point 7 & 92.07 & 3.75 & 0.55 & 0.13 & 0.23 & 0.00 & 0.15 & 0.15 & 0.11 & 0.31 & 0.17 & 0.47 & 0.21 & 0.69 & 1.01 & 100.00 \\
\hline Point 8 & 91.19 & 3.86 & 1.22 & 0.00 & 0.30 & 0.10 & 0.27 & 0.26 & 0.13 & 0.35 & 0.42 & 0.49 & 0.30 & 0.53 & 0.58 & 100.00 \\
\hline Point 9 & 90.22 & 5.20 & 1.12 & 0.14 & 0.14 & 0.17 & 0.14 & 0.15 & 0.10 & 0.27 & 0.33 & 0.53 & 0.00 & 0.60 & 0.89 & 100.00 \\
\hline Point 10 & 92.24 & 1.83 & 0.94 & 0.20 & 0.25 & 0.38 & 0.31 & 0.18 & 0.20 & 0.38 & 0.29 & 0.54 & 1.16 & 0.61 & 0.53 & 100.00 \\
\hline Avg matrix & 91.64 & 3.73 & 0.79 & 0.14 & 0.20 & 0.07 & 0.22 & 0.21 & 0.16 & 0.31 & 0.23 & 0.50 & 0.31 & 0.70 & 0.78 & 100.00 \\
\hline SD matrix & 1.17 & 1.13 & 0.31 & 0.10 & 0.12 & 0.12 & 0.06 & 0.12 & 0.05 & 0.10 & 0.11 & 0.13 & 0.54 & 0.27 & 0.30 & \\
\hline \multicolumn{17}{|c|}{ Sample 3 (Chase Part 3) } \\
\hline \multicolumn{17}{|l|}{ Matrix } \\
\hline Point 1 & 89.82 & 5.07 & 0.89 & 0.13 & 0.29 & 0.00 & 0.33 & 0.23 & 0.23 & 0.23 & 0.59 & 0.39 & 0.61 & 0.66 & 0.54 & 100.00 \\
\hline Point 2 & 91.20 & 2.91 & 1.05 & 0.13 & 0.36 & 0.00 & 0.28 & 0.26 & 0.21 & 0.37 & 0.65 & 0.98 & 0.00 & 0.72 & 0.87 & 100.00 \\
\hline Point 3 & 90.44 & 4.08 & 1.26 & 0.23 & 0.32 & 0.24 & 0.29 & 0.24 & 0.24 & 0.60 & 0.41 & 0.36 & 0.00 & 0.49 & 0.81 & 100.00 \\
\hline Point 4 & 90.62 & 3.58 & 1.14 & 0.10 & 0.26 & 0.00 & 0.23 & 0.29 & 0.37 & 0.45 & 0.37 & 0.66 & 0.13 & 0.70 & 1.10 & 100.00 \\
\hline Point 5 & 91.13 & 1.67 & 1.48 & 0.28 & 0.12 & 0.00 & 0.25 & 0.33 & 0.45 & 0.27 & 0.40 & 0.92 & 0.97 & 0.82 & 0.93 & 100.00 \\
\hline Point 6 & 89.75 & 3.88 & 1.12 & 0.00 & 0.26 & 0.15 & 0.30 & 0.31 & 0.20 & 0.38 & 0.73 & 0.66 & 0.44 & 0.78 & 1.04 & 100.00 \\
\hline Point 7 & 89.80 & 4.59 & 1.03 & 0.16 & 0.21 & 0.20 & 0.29 & 0.37 & 0.11 & 0.40 & 0.39 & 0.62 & 0.00 & 0.85 & 0.99 & 100.00 \\
\hline Point 8 & 90.57 & 0.87 & 1.43 & 0.10 & 0.21 & 0.00 & 0.38 & 0.59 & 0.20 & 0.44 & 0.77 & 1.18 & 1.69 & 1.14 & 0.44 & 100.00 \\
\hline Point 9 & 89.24 & 0.89 & 1.43 & 0.00 & 0.52 & 1.15 & 0.45 & 0.40 & 0.13 & 1.15 & 0.60 & 0.80 & 1.26 & 1.40 & 0.58 & 100.00 \\
\hline Point 10 & 88.92 & 5.45 & 0.78 & 0.00 & 0.19 & 0.00 & 0.37 & 0.37 & 0.32 & 0.40 & 0.74 & 0.31 & 0.29 & 0.67 & 1.20 & 100.00 \\
\hline Avg matrix & 90.15 & 3.30 & 1.16 & 0.11 & 0.27 & 0.17 & 0.32 & 0.34 & 0.25 & 0.47 & 0.57 & 0.69 & 0.54 & 0.82 & 0.85 & 100.00 \\
\hline SD matrix & 0.77 & 1.67 & 0.24 & 0.10 & 0.11 & 0.35 & 0.07 & 0.11 & 0.11 & 0.26 & 0.16 & 0.29 & 0.59 & 0.26 & 0.26 & \\
\hline \multicolumn{17}{|l|}{ Sample 4 (chase) } \\
\hline \multicolumn{17}{|l|}{ Zone 1 matrix } \\
\hline Point 1 & 89.40 & 5.27 & 0.95 & 0.00 & 0.40 & 0.00 & 0.46 & 0.15 & 0.41 & 0.31 & 0.68 & 0.70 & 0.00 & 0.41 & 0.86 & 100.00 \\
\hline \multicolumn{17}{|l|}{ Zone 1 inclusion } \\
\hline Point 2 & 70.23 & 3.79 & 0.45 & 0.19 & 0.00 & 22.34 & 0.44 & 0.27 & 0.20 & 0.37 & 0.36 & 0.34 & 0.00 & 0.00 & 1.03 & 100.00 \\
\hline Point 3 & 69.16 & 2.78 & 0.75 & 0.40 & 0.00 & 23.36 & 0.38 & 0.18 & 0.19 & 0.35 & 0.60 & 0.32 & 1.05 & 0.00 & 0.49 & 100.00 \\
\hline
\end{tabular}


Table 1 (continued)

\begin{tabular}{|c|c|c|c|c|c|c|c|c|c|c|c|c|c|c|c|c|}
\hline & $\mathrm{Cu}$ & $\mathrm{Pb}$ & Sn & Al & $\mathrm{Si}$ & $\mathrm{S}$ & $\mathrm{Ti}$ & $\mathrm{Cr}$ & $\mathrm{Mn}$ & $\mathrm{Fe}$ & $\mathrm{Ni}$ & $\mathrm{Zn}$ & As & $\mathrm{Ag}$ & $\mathrm{Sb}$ & Total \\
\hline \multicolumn{17}{|c|}{ Zone 2 inclusion } \\
\hline Point 4 & 69.08 & 4.15 & 1.04 & 0.13 & 0.13 & 22.14 & 0.45 & 0.24 & 0.20 & 0.81 & 0.39 & 0.33 & 0.00 & 0.24 & 0.67 & 100.00 \\
\hline \multicolumn{17}{|l|}{ Zone 2 matrix } \\
\hline Point 5 & 92.29 & 1.76 & 0.99 & 0.13 & 0.28 & 0.00 & 0.26 & 0.24 & 0.17 & 0.31 & 0.31 & 0.58 & 0.50 & 0.63 & 1.57 & 100.00 \\
\hline \multicolumn{17}{|c|}{ Zone 3 inclusion } \\
\hline Point 6 & 70.29 & 4.67 & 0.40 & 0.19 & 0.00 & 21.30 & 0.25 & 0.37 & 0.17 & 0.27 & 0.41 & 0.33 & 0.14 & 0.40 & 0.81 & 100.00 \\
\hline \multicolumn{17}{|l|}{ Zone 3 matrix } \\
\hline Point 7 & 92.54 & 2.26 & 0.83 & 0.00 & 0.10 & 0.13 & 0.47 & 0.35 & 0.19 & 0.31 & 0.31 & 0.26 & 0.26 & 1.10 & 0.88 & 100.00 \\
\hline \multicolumn{17}{|l|}{ Zone 4 matrix } \\
\hline Point 8 & 90.53 & 4.67 & 1.49 & 0.00 & 0.10 & 0.18 & 0.19 & 0.13 & 0.00 & 0.29 & 0.45 & 0.41 & 0.15 & 0.44 & 0.99 & 100.00 \\
\hline Point 9 & 90.10 & 5.40 & 0.82 & 0.33 & 0.00 & 0.00 & 0.30 & 0.22 & 0.14 & 0.44 & 0.31 & 0.65 & 0.00 & 0.76 & 0.55 & 100.00 \\
\hline Point 10 & 91.62 & 3.02 & 1.19 & 0.00 & 0.13 & 0.00 & 0.37 & 0.16 & 0.00 & 0.34 & 0.60 & 0.70 & 0.24 & 0.91 & 0.73 & 100.00 \\
\hline Point 11 & 90.43 & 4.17 & 1.01 & 0.15 & 0.18 & 0.00 & 0.18 & 0.39 & 0.19 & 0.35 & 0.33 & 0.79 & 0.00 & 0.64 & 1.19 & 100.00 \\
\hline Point 12 & 90.49 & 3.26 & 1.30 & 0.11 & 0.21 & 0.15 & 0.50 & 0.34 & 0.19 & 0.41 & 0.69 & 0.34 & 0.34 & 1.05 & 0.63 & 100.00 \\
\hline Point 13 & 89.05 & 5.19 & 1.03 & 0.00 & 0.43 & 0.00 & 0.25 & 0.32 & 0.20 & 0.53 & 0.42 & 0.73 & 0.40 & 0.95 & 0.51 & 100.00 \\
\hline Avg matrix & 90.72 & 3.89 & 1.07 & 0.08 & 0.20 & 0.05 & 0.33 & 0.25 & 0.16 & 0.37 & 0.46 & 0.57 & 0.21 & 0.76 & 0.88 & 100.00 \\
\hline SD matrix & 1.21 & 1.37 & 0.22 & 0.11 & 0.14 & 0.08 & 0.12 & 0.10 & 0.12 & 0.08 & 0.16 & 0.19 & 0.19 & 0.25 & 0.34 & \\
\hline Avg all matrix & 91.00 & 3.77 & 1.01 & 0.10 & 0.23 & 0.09 & 0.28 & 0.25 & 0.18 & 0.34 & 0.41 & 0.53 & 0.28 & 0.76 & 0.76 & 100.00 \\
\hline
\end{tabular}

Teutonic or Polish workshop. Its Rus-Lithuanian manufacture seems much less probable, as all known early firearms from this part of Europe are iron. A Teutonic provenance of the Grodno gun could only tentatively be supposed, based on an established tradition of manufacture of copper guns by the Order. It must be remembered, however, that much more is known on the technology of manufacture of firearms in the Teutonic Order's state than in Poland in the discussed period ([2], p. 214-232). As mentioned, $\mathrm{Sb}$ impurities were also found in the metal of the Teutonic cannon from Kurzętnik (Kauernick). What is more, sulphide-rich copper ores may have been used to obtain the metal in the case of both these guns. However, these similarities are certainly not enough to propose a common provenance of these cannons.

A few attempts at assessing the provenance of metal in copper alloy firearms have been undertaken in previous research. Concerning two late medieval hand-held guns from Kalisz and from Wenecja (both in Greater Poland), on the basis of the content of As (1.19\% and $1.56 \%$ respectively) a Polish source of metal has been proposed, but with no further details. Regarding the late medieval hand-held guns from Rakov and from Valečov in Bohemia, it has been suggested that the contents of $\mathrm{Ag}$ and $\mathrm{Sb}$ (Rakov-2.1\% Ag and 2.4\% Sb; Valečov-0.26\% $\mathrm{Ag}$ and $0.58 \% \mathrm{Sb}$ ) may imply that the metal came from Bohemian mines in Kutna Hora ([2], p. 229-230). As far as three copper alloy late 16 th-early 17 th c. Venetian cannons from the wreck site of Megadim in Israel are concerned, Ashkenazi et al. have stated that similarities in their chemistry may suggest the same raw material. Furthermore, they have suggested that $\mathrm{Pb}$ isotopic examinations may be of use to assess the metal's provenance. This, however, could be related to certain difficulties, as in two cannons the content of $\mathrm{Pb}$ was below $1 \mathrm{wt} \%$ ([5], p. 101).

In the recent years there has been a considerable progress in copper provenance analyses using $\mathrm{Pb}$ isotopic ratios, often combined with minor elements (e.g., Sb, As, $\mathrm{Ni}$, and others) (for a historical outline and a theoretical background see, e.g., [62-64]). Hauptmann et al. discussed Late Chalcolithic and Early Bronze Age artefacts from Arslantepe in Anatolia [65]. Pb isotopic ratios were used by Niederschlag et al. for the purpose of defining the provenance of Early Bronze Age copper and bronze artefacts from Bohemia, Central Germany and Poland [66]. Prehistoric copper ore mining in the Eastern Alps has been a subject of several studies on the basis of $\mathrm{Pb}$ isotopic ratios and trace elements (Ag, $\mathrm{Sb}, \mathrm{Ni}, \mathrm{As}$, and others) [67-69]. Pryce et al. have carried out a broad-scale study on South Eastern Asian copper alloy exchange in the period of c. 1000 BC-c. 500 AD [70]. Pollard et al. paid attention to behaviour of certain elements (As, Sb, $\mathrm{Ag}, \mathrm{Ni}$ ) in alloys during alloy re-melting and their significance in characterising the metal during its life history. Combined with observations on the contents of Sn, $\mathrm{Zn}$, and $\mathrm{Pb}$ as major alloying elements, this allowed for a new look on patterns of copper alloy recycling. These scholars also proposed a new approach, where the $\mathrm{Pb}$ chemical concentration is used together with its isotopic ratios 


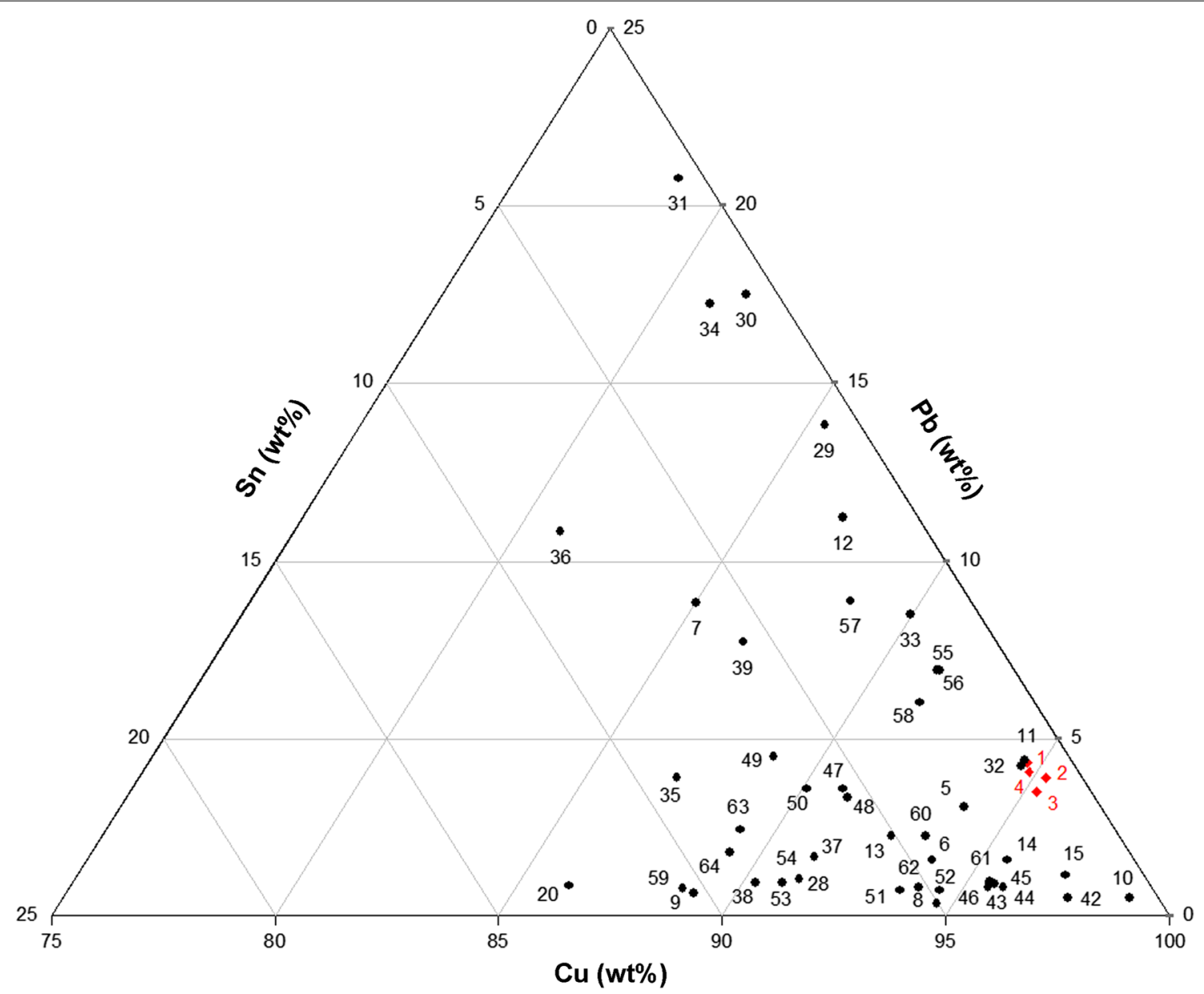

Fig. $14 \mathrm{Cu}-\mathrm{Pb}-\mathrm{Sn}$ ternary graph of the Grodno cannon's chemistry against the background of comparative data. Legend: 1-4: Grodno, Rus; 5: Loshut, Sweden; 6: Otepää, Livonia; 7: Kalisz, Greater Poland; 8: Rakov, Bohemia; 9: Rokštejn, Moravia; 10: Wenecja, Greater Poland; 11: Valečov, Bohemia; 12: Karpenstein, Silesia; 13: Smederovo, Serbia, 14: Gun 1, Mstěnice, Moravia; 15: Gun 2, Mstěnice, Moravia; 20: Grose Bochse, Marienburg, Teutonic Order; 28: Cannon 1, Sv Pavao wreck, Mljet, Croatia; 29-31: Cannon 2, Sv Pavao wreck, Mljet, Croatia; 32-34: Cannon 2, Sv Pavao wreck, Mljet, Croatia; 35: Cannon 4, Sv Pavao wreck, Mljet, Croatia; 36: Cannon 5, Sv Pavao wreck, Mljet, Croatia; 37: Cannon 6, Sv Pavao wreck, Mljet, Croatia; 38: Cannon 7, Sv Pavao wreck, Mljet, Croatia; 39: Cannon 8, Sv Pavao wreck, Mljet, Croatia; 42: Benin, Nigeria; 43-46: Cannon A, Megadim wreck site, Israel; 47-50: Cannon B, Megadim wreck site, Israel; 51-54: Cannon C, Megadim wreck site, Israel; 55-58: Chamber 1, Megadim wreck site, Israel; 59: South North Sea; 60-64: cannons from Euro-Maasgeul Channel (for details see Additional file 1: Sheet 1)

[71]. Rademakers et al. investigated copper provenance in Late Bronze Age Egypt [72], and the provenance of copper artefacts from the Early-Middle Copper Age in the Great Hungarian Plain was discussed by Siklósi and Szilágyi [73]. Nørgaard et al. discussed questions of provenance and circulation of copper alloys in Early Bronze Age Scandinavia [74]. There is also a recent provenance study by Kowalski et al. on the basis of $\mathrm{Ag}-\mathrm{Sb}$ and $\mathrm{Pb} /$ As-Pb bivariate scatterplots [75]. The state of debate on the provenance and use of metals in Bronze Age Europe has recently been discussed by Radivojević et al. They reviewed a number of issues, including research and presentation standards, or a significance of open access online data repositories (OXALID and others). Attention was paid to methods of provenancing and their limitations, especially those caused by recycling and mixing of metal. Questions of copper distribution and circulation patterns were also dealt with [76].

However, on the basis of the available data it is impossible to propose the provenance of the metal of the light field cannon from Grodno. This issue requires a separate study, which must commence with an investigation of resources and trade patterns of copper, tin and lead in this part of Europe in the Late Middle Ages. A lot of information can be obtained from written sources. For instance, it is known that part of copper for the Teutonic Grose Bochse from 1408 came from Banská Bystrica (Besztercebánya) in Upper Hungary 
(present-day Slovakia) ([46], p. 33) (on Upper Hungarian copper ore mines see, e.g., [77], p. 88]). Numerous impurities that are present in the metal of the Grodno gun ( $\mathrm{Sb}, \mathrm{Ag}$ and others) may be of use in selecting possible ore sources of which the cannon's metal may have been smelted. As it can be seen, the Ag and/or Sb contents that were found in the Grodno cannon are similar to those reported for some late medieval firearms from Central Europe (Additional file 1: Sheet 1, Nos. 7, 12,14 , and 15), which may offer a hint in future provenance studies.

\section{Conclusions and suggestions for further research}

The discussed cannon from Grodno is a very interesting example of early firearms from Eastern Europe. It seems to be a rather typical representative of light field cannons, both with regard to its morphology and the chemical composition of the alloy. Concerning the latter trait, attention is drawn to a high amount of $\mathrm{Pb}$, which may have been added to the alloy in order to facilitate the casting process. On the basis of both archaeological and historical evidence as well as available analogies, the late $14^{\text {th }} \mathrm{c}$. chronology of the artefact can be safely proposed. The cannon must have been related to the troops that participated in the hostilities over Grodno in the period in question. Its Teutonic manufacture could only speculatively be proposed and on the basis of available data nothing can be said on the provenance of its metal. On the other hand, both the Grodno gun and the Teutonic cannon from Kurzętnik (Kauernick) were made from the copper alloy with $\mathrm{Sb}$ impurities, and in both cases the metal may have been smelted of sulphide-rich copper ores. Furthermore, the Ag and/or Sb contents in the Grodno gun metal are similar to those in some Central European firearms. All this can be of use in a future provenance study of this cannon.

It can be hoped that technological examinations of medieval and modern period firearms will continue and more will be known on methods of their manufacture. Eventually, new technological analyses may also bring more data that would allow for more advanced provenance studies of old firearms. Concerning copper alloy gun manufacture in the Teutonic Order's state, a great research potential rests in archaeological finds from the foundry area at the Castle of Marienburg (Malbork). Furthermore, the metal of the Teutonic cannon from Kurzętnik (Kauernick) can be re-examined in order to obtain more detailed data on its chemistry. It is therefore highly recommended to carry on a provenance study on the Grodno gun with the most up-to-date scientific methods.
Abbreviations

SEM: Scanning electron microscopy; EDS: Energy dispersive spectroscopy; XRF: $\mathrm{X}$-ray fluorescence.

\section{Supplementary Information}

The online version contains supplementary material available at https://doi. org/10.1186/s40494-021-00534-z.

Additional file 1. Chemistry of late medieval and modern period copper alloy European firearms.

\section{Acknowledgements}

The authors are obliged to Ms Natalia Kiziukevič, Head of the Archaeology Department of the State Historical and Archaeological Museum in Grodno, Belarus for valuable pieces of information concerning the find context, photographical documentation and samples of the cannon. Thanks must also go to Captain Yurii Kulikov from Crimea and to Dr Alexandr Strelčenko for their valuable remarks and help with access to Russian literature. Captain Kulikov was also kind enough to provide the authors with the drawings of the Stary Krym cannon. Eventually, the authors are indebted to three anonymous reviewers, whose insightful comments significantly improved this paper.

\section{Authors' contributions}

PS and GŻ initiated this research and discussed the archaeological and historical contexts of the find. GŻ carried out sample preparation and microscopic observations, whereas TG and KA offered valuable remarks on the metal's microstructure. TG performed EDS analyses, while GŻ was responsible for data processing. EM-J provided important comments on the composition of archaeological copper alloys. All authors read and approved the final manuscript.

\section{Funding}

This work was not funded by any research project.

Availability of data and materials

The raw data used in this manuscript is available as Additional file (Excel).

Ethics approval and consent to participate

Not applicable.

Consent for publication

Not applicable.

\section{Competing interests}

The authors declare no conflict of interest.

\section{Author details}

${ }^{1}$ Institute of History, Jan Długosz University, Częstochowa, Poland. ${ }^{2}$ Institute of Archaeology, Uniwersity of Łódź, Łódź, Poland. ${ }^{3}$ Institute of Materials Science, University of Silesia, Katowice, Poland. ${ }^{4}$ National Centre for Nuclear Research, Świerk, Otwock, Poland.

Received: 22 February 2021 Accepted: 12 May 2021

Published online: 05 June 2021

\section{References}

1. Davies J. The Medieval Cannon 1326-1494. New Vanguard 273. Oxford: Osprey Publishing; 2019.

2. Strzyż P. Broń palna w Europie Środkowej w XIV-XV w. (Firearms in Central Europe in the 14th-15th c.). Łódź: Polska Akademia Nauk, Instytut Archeologii i Etnologii; 2014.

3. McLachlan S. Medieval handgonnes. The first black powder infantry weapons. Osprey Weapon 3. Oxford: Osprey Publications; 2010.

4. Smith RD, DeVries K. The Artillery of the Dukes of Burgundy, 1363-1477. Woodbridge: Boydell Press; 2005. 
5. Ashkenazi D, Cvikel D, Langgut D, Rosen B, Galili E. Artillery and rigging artefacts from the Megadim wreck-site, Israel. J Archaeol Sci Reports. 2017;14:91-105. https://doi.org/10.1016/j.jasrep.2017.05.031.

6. Mustaček M, Ćurković M, Jozić A, Jelić A. Appendix: The Conservation and Restoration of the Finds. In: C. Beltrame, S. Gelichi, I. Miholjek, editors. Sveti Pavao Shipwreck A $16^{\text {th }}$ Century Venetian Merchantman from Mljet, Croatia. Oxford: Oxbow Books; 2014, 154-166. https:// iris. unive. it/retri eve/ handle/ 10278/ 39554/ 29994/ Sveti Pavao Shipw reck PRINT ER File29. 05. 14. pdf.. Accessed 18 Dec 2020.

7. Smith RD. The technology of wrought-iron artillery. Royal Armouries Yearbook. 2000;5:68-79.

8. Smith RD, Brown RR. Bombards Mons Meg and her sisters. Royal Armouries Monograph 1. London: Royal Armouries; 1989.

9. Żabiński G. Technology of manufacture of firearms in the Teutonic Order's state in Prussia - gun barrels and metal projectiles. Fasciculi Archaeologiae Historicae (From the Problems of Historical Archaeology). 2015;28:83-110. https://journals.iaepan.pl/fah/article/view/1488. Accessed 20 Feb 2021.

10. Żabiński G, Biborski M, Miśta-Jakubowska E. A late medieval or early modern light gun barrel from the Castle Museum in Malbork-typology, technology of manufacture and identification of the smelting process. Archaeol Anthropol Sci. 2019;11(5):2007-26. https://doi.org/10.1007/ s12520-018-0653-3.

11. Żabiński G, Biborski M, Biborski M, Stępiński J, Miśta-Jakubowska E. A late medieval or early modern ferrous hackbut barrel from the collection of the Castle Museum in Malbork. Acta Militaria Mediavalia 2018;14:175207. http://amm.sanok.pl/wp-content/uploads/2020/12/08_-Zabinski_ Biborski_Biborski_Stepinski_Mista-Jakubowska_AMM_XIV.pdf. Accessed 4 Apr 2021.

12. Volkau MA. Arhitektura Staroga zamka y Grodna y XVI-XVIII stst.: vzglyad i pryznačenne zbydavannyau razmešč uzdouž niomanskay scyany (Architecture of Old Castle in Grodno in the 16th-18th c.: view and functions of buildings along the Neman wall). Belaruski gistaričny časopis. 2015;11:522. https://www.academia.edu/19861677. Accessed 15 Feb 2021.

13. Volkau MA. Arhitektura Staroga zamky časou Vitauta u Garodni (Architecture of Old Castle in Grodno in the times of Vytautas). Belaruski gistaričny časopis 2014;2:17-34. https://www.academia.edu/6225236. Accessed 15 Feb 2021.

14. Volkau MA. Ab nekatoryh aspektah arhitektury Staroga zamka u Garodni časou Stefana Batorya (Some aspects of the architecture of the Old Castle in Grodno in the times of Stephen Báthory). Krayauznayčya zapiski 2013;9:16-20. https://www.academia.edu/7631863. Accessed 15 Feb 2021.

15. Wigand von Marburg. Die Chronik Wigands von Marburg (The Chronicle of Wigand of Marburg). In: T Hirsch, editor. Scriptores Rerum Prussicarum (Writers of the Prussian History) 2. Leipzig: Verlag von S. Hirzel; 1863. p. 429-662. https://www.wbc.poznan.pl/dlibra/publication/13116/edition/ 21001. Accessed 4 Apr 2021.

16. Franciscani Thorunensis Annales Prussici (941-1410) (Prussian Annals of a Toruń Franciscan Friar, 941-1410). In: E Strehlke, editor. Scriptores rerum Prussicarum (Writers of the Prussian History) 3. Leipzig: Verlag von S. Hirzel; 1866. p. 13-399. https://www.wbc.poznan.pl/dlibra/publication/ 13117/edition/21000. Accessed 4 Apr 2021.

17. Nikodem J. Witold wielki książę litewski (1354 lub 1355 - 27 października 1430) (Vytautas Grand Duke of Lithuania, 1354 or 1355 - 27 October 1430). Kraków: Avalon; 2013.

18. Posilge J. Johanns von Posilge, Officials von Pomesanien, Chronik des Landes Preussen (von 1360 an, fortgesetzt bis 1419) zugleich mit den auf Preussen bezuglichen Abschnitten aus der Chronik Detmar's von Lübeck (The Chronicle of the Land of Prussia (from 1360, continued to 1419), by Johann von Posilge, an Official from Pomesania, together with excerpts concerning Prussia from the Chronicle of Detmar von Lübeck). In: E Strehlke, editor. Scriptores rerum Prussicarum (Writers of the Prussian History) 3. Leipzig: Verlag von S. Hirzel; 1866. p. 13-399. https://www.wbc.poznan. pl/dlibra/publication/13117/edition/21000. Accessed 4 Apr 2021.

19. Długosz J. Iohannis Dlugossi Annales seu Cronicae Incliti Regni Poloniae (Jan Długosz's Annals or Chronicles of the Famous Kingdom of Poland). Liber X 1370-1405. Editors S. Gawęda, A. Kamiński, M. Kowalczyk, S. Kozłowska-Budkowa, S. Mikucki, J. Mitkowski, S. Perzanowski, C. Pieradzka, M. Plezia, D. Turkowska, W. Semkowicz-Zarembina. Varsaviae: Państwowe Wydawnictwo Naukowe; 1985. https://polona.pl/item/ioannis-dlugo
ssi-annales-seu-cronicae-incliti-regni-poloniae-liber-10-1370-1405,MzczM TU3MTA/8/\#info:metadata. Accessed 4 Apr 2021.

20. Stępiński J, Żabiński G, Strzyż P. The light field cannon from Kurzętnik - a unique example of medieval artillery (against the background of development of firearms in the Teutonic Order's state in Prussia). Acta Militaria Mediaevalia 2013;9:155-202. http://amm.sanok.pl/wp-content/uploads/ 2017/06/IX.6_Stępinski-et-al.pdf. Accessed 4 Apr 2021.

21. Die Ältere Hochmeisterchronik (The Older Chronicle of the Grand Masters). In: M Toeppen, editor. Scriptores Rerum Prussicarum (Writers of the Prussian History) 3. Leipzig: Verlag von S. Hirzel; 1866. p. 519-709. https:// www.wbc.poznan.pl/dlibra/publication/13117/edition/21000. Accessed 4 Apr 2021.

22. Schmidtchen V. Die Feuerwaffen des Deutschen Ritterordens bis zur Schlacht bei Tannenberg 1410: Bestände, Funktion und Kosten, dargestellt anhand der Wirtschaftsbücher des Ordens von 1374 bis 1410 (Firearms of the Teutonic Order to the battle of Tannenberg in 1410. Resources, function and costs, discussed on the basis of the Order's account books from 1374 to 1410). Lüneburg: Nordostdeutsches Kulturwerk; 1977.

23. Szymczak J. Początki broni palnej w Polsce 1383-1533 (Beginnings of firearms in Poland 1383-1533). Łódź: Wydawnictwo Uniwersytetu Łódzkiego; 2004.

24. Prodolzene letopisi po Voskresenskomu spisku (A continuation of the Resurrection chronicle). In: Polnoe sobrane russkih letopisey (The complete collection of Russian chronicles) Vol. 8. Sankt Petersburg: Tipografia Eduarda Praca; 1859. http://psrl.csu.ru/data/PSRL_T.08_Izd.01_1859.djvu. Accessed 4 Apr 2021.

25. Novgorodskaya četvertaya letopis (The fourth chronicle of Novgorod). In: Polnoe sobrane russkih letopisey (The complete collection of Russian chronicles) Vol. 4.1. $2^{\text {nd }}$ ed. Leningrad: Izdatelstvo Akademii Nayk SSSR; 1925. http://psrl.csu.ru/data/PSRL_T.04_Izd.02 Ch.01_Vyp.2_1925.djvu. Accessed 4 Apr 2021.

26. Letopisny sbornik imenuemy Patriaršeyu ili Nikonovskoyu letopisyu (The chronicle collection named the Patriarchal or Nikon chronicle). In: Polnoe sobrane russkih letopisey (The complete collection of Russian chronicles) Vol. 11. Sankt Petersburg:Tipografia I. N. Skorohodova; 1897. http://psrl. csu.ru/data/PSRL_T.11_Izd.01_1897.djvu. Accessed 4 Apr 2021.

27. Letopisny sbornik, imenuemy Tverskoyu letopisyu (The chronicle collection named the Tver chronicle). In: Polnoe sobrane russkih letopisey (The complete collection of Russian chronicles) Vol. 15. Sankt Petersburg: Tipografia Leonida Demisa; 1863. http://psrl.csu.ru/data/PSRL_T.15_Izd. 01_1863.djvu. Accessed 4 Apr 2021.

28. Novgorodskye i pskovskye letopisi (Novgorod and Pskov chronicles). In: Polnoe sobrane russkih letopisey (The complete collection of Russian chronicles) Vol. 4. Sankt Petersburg: Tipografia Eduarda Praca; 1848. http://psrl.csu.ru/data/PSRL_T.04_Izd.01_1848.djvu. Accessed 4 Apr 2021.

29. Ulyanov OG. Drevneyšy arsenal w Moskovskom Kremle - mesto roždenya russkoy artilerii (The old arsenal of the Moscow Kremlin - a birthplace of Russian artillery). In: Voina i oruže. Novye issedovanya i materialy. Trudy $\checkmark$ meždunarodnoy naučno-praktičeskoy konferencii 14-16 maya 2015 g. (War and weapons. New research and materials. Proceedings of the $5^{\text {th }}$ scientific-practical conference, 14-16 May 2015) Part 4. Sankt Petersburg: Voenno-istoričeski muzey artilerii, inženernyh voisk i voisk svyazi; 2015. p. 220-243. https://www.academia.edu/18488433/. Accessed 4 Apr 2021.

30. Kirpičnikov AN. Voennoe delo na Rusi v XIII-XV vv. (The art of war in Russia in the $13^{\text {th }}-15^{\text {th }}$ C.) Leningrad: Izdatelstvo Nauka; 1976.

31. Wilinbachow W. Początkowy okres rozwoju broni palnej w krajach słowiańskich (Initial period of development of firearms in Slavic countries). Kwartalnik Historii Nauki i Techniki. 1963;8(2):215-235. http:// bazhum.muzhp.pl/media/files/Kwartalnik_Historii_Nauki_i_Techniki/ Kwartalnik_Historii_Nauki_i_Techniki-r1963-t8-n2/Kwartalnik_Historii_ Nauki_i_Techniki-r1963-t8-n2-s215-235/Kwartalnik_Historii_Nauki_i_ Techniki-r1963-t8-n2-s215-235.pdf. Accessed 4 Apr 2021.

32. Kulikov Y. Ouery - Cannons in the Crimea. Ordnance Society Newsletter October 2016;115:27-28. https://www.academia.edu/29216890/. Accessed 31 Oct 2019.

33. Pskovskaya vtoraya i Sofiyskaya pervaya letopis (The second chronicle of Pskov and the first chronicle of Sofia). In: Polnoe sobrane russkih letopisey (The complete collection of Russian chronicles) Vol. 5. Sankt Petersburg: Tipografia Eduarda Praca; 1851. http://psrl.csu.ru/data/PSRL_T.05_Izd.01_ 1851.djvu. Accessed 4 Apr 2021. 
34. Letopisny sbornnik, imenuemy letopisyu Avraamki (The chronicle collection named the Avraamka collection). In: Polnoe sobrane russkih letopisey (The complete collection of Russian chronicles) Vol. 16. Sankt Petersburg: Tipografia E. Eneopskogo i Ko; 1889. http://psrl.csu.ru/data/ PSRL_T.16_1889.djvu. Accessed 4 Apr 2021.

35. Dopolnenya k aktam istoričeskim, sobrannya i izdannya arheologičeskoyu kommisyeu (Supplements to historical sources, collected and published by the Archaeological Commission). Vol. 5. Sankt Petersburg: V tipografii Eduarda Praca; 1853. https://runivers.ru/upload/iblock/988/Dopolneniy akaktamistoricheskimT5.pdf. Accessed 4 Apr 2021.

36. Kulikov Y. Istoria vozniknovenya artilerii i pervye artilleriyskye orudya $v$ Krymu (A history of the origin of artillery and the first cannons in Crimea). Military Krym. Voensko-istoričeski žurnal 2017;31.1:59-62. https://www. academia.edu/31937747/. Accessed 4 Apr 2021.

37. Malčenko O. Museum artilleriae ucrainicae saeculi XV-XVIII pars prima (Museum of the Ukrainian artillery of the $15^{\text {th }}-18^{\text {th }}$ C. Part I). Kiovia: Institut Ukrainskoi Arheografii ta Džereloznavstva Narodnoi Akademii Nauk Ukrainy; 2011. http://history.org.ua/LiberUA/978-966-02-6052-5/978-96602-6052-5.pdf. Accessed 4 Apr 2021.

38. Makovskaya LK. Ručnoe ognestelnoe oruže russkoy armii konca XIV-XVIII v. (Hand-held firearms of the Russian army, late $14^{\text {th }}-18^{\text {th }}$ c.). Moskva: Voennoe Izdatelstvo; 1992.

39. Milyaev PA. Nahodki detaley ručnogo ognestelogo vooruženya vtoroy poloviny XV-XVI v. iz Staroy Ladogi i kreposti Orešek v svete vostočno- i zapadnoevropeiskih analogii (Finds of parts of hand-held firearms from the second part of the $15^{\text {th }}$ to the $16^{\text {th }} \mathrm{c}$. from Staraya Ladoga and the fortress of Orešek in the light of Eastern and Western European analogies). Arheologičeske vesti 2018;24:218-238. http://www.archeo.ru/doi/ av/av-24/24Miliajev.pdf. Accessed 4 Apr 2021.

40. Strzyż P. Broń palna W Polsce średniowiecznej. Studium archeologiczne (Firearms in medieval Poland. An archaeological study). Łódź: Polska Akademia Nauk, Instytut Archeologii i Etnologii; 2011.

41. Lazar T. The oldest preserved gun in Slovenia. In: G Oitzl, A Miškec, editors. The Past under the Microscope. Scientific Analyses in Museums. Ljubljana: Narodni Muzej Slovenije; 2018. p 86-96. https://www.acade mia.edu/38396353/. Accessed 4 Apr 2021.

42. Ilijić G. Nalazi topova sa prostora Beogradske tvrdave kao svedočanstva ugarsko-turskih borbi za Beograd (Cannon finds from the Fortress of Belgrade as a testimony of the Hungarian-Turkish fights for Belgrade). Vesnik 2009;36:18-28. http://elibrary.matf.bg.ac.rs/bitstream/handle/123456789/ 590/GoranllijicNalaziTopovaSaProstoraBeogradskeTvrdjave.pdf?seque nce=1. Accessed 4 Apr 2021.

43. Anleitung, Schiesspulver zu bereiten Büchsen zu laden und zu beschiessen (An instruction how to charge ready guns with gunpowder and how to fire them) (c. 1400/1410). Bayerische Staatsbibliothek, München, Cgm 600. https://daten.digitale-sammlungen.de/ db/0011/bsb00113907/ images/. Accessed 2 Feb 2021.

44. Das Buch von der Büchsenmeisterei (The Book of Gunmastery) (1462/1463), Germanisches Nationalmuseum, Nürnberg, Hs 719. http:// dlib.gnm.de/item/Hs719/1. Accessed 1 Aug 2020.

45. Zeugbuch Kaiser Maximilians I (The Book of Armaments of Emperor Maximilian I) (c. 1502). Innsbruck. Bayerische Staatsbibliothek München, Cod. Icon. 222. https://daten.digitale-sammlungen.de/ db/0002/bsb00 020956/images/. Accessed 30 May 2015.

46. Żabiński G. The Grose bochse - a Teutonic Supergun from 1408. Fasciculi Archaeologiae Historicae 2012;25:31-40. https://www.academia.edu/ 3557136. Accessed 21 Feb 2021.

47. Williams AR, Paterson AJR. A Turkish bronze cannon in the Tower of London. Gladius 1986;17:185-205. http://gladius.revistas.csic.es/index.php/ gladius/article/view/122/122. Accessed 10 May 2020

48. Biringuccio V. The Pirotechnia of Vannoccio Biringuccio. The Classic Sixteenth-Century Treatise on Metals and Metallurgy. Translated and edited by C. S. Smith and M. Teach Gnudi (an unabridged republication of the 1959 edition by The American Institute of Mining and Metallurgical Engineers, Inc.; original edition: De la pirotechnia. Libri X. C. Navò, Venetia 1540). Mineola-New York: Dover Publications; 2005.

49. Dąbrowska M. Proces odlewania dział w lejni malborskiej w XV wieku (Process of gun casting at the Malbork foundry in the $15^{\text {th }} \mathrm{C}$.). Archaeologia Historica Polona 2009;18:21-44.

50. Dąbrowska M. Badania archeologiczno-architektoniczne na terenie Zamku Niskiego w Malborku w latach 1998-2004
(Archaeological-architectural research in the area of the Low Castle in Malbork in 1998-2004). In: G Nawrolska, editor. XV Sesja Pomorzoznawcza. Materiały z konferencji 30 listopada-2 grudnia 2005 r. (1 $5^{\text {th }}$ Session of Studies on Pomerania. Conference proceedings, 30 November-2 December 2005). Elbląg: Muzeum Archeologiczno-Historyczne w Elblągu; 2007. p. 303-316.

51. Belényesy K. Cannon foundry workshop in late medieval Buda (Hungary) at the turn of the 15 th-16th centuries. In: Thomas N, Dandridge P, editors. Cuivre, bronzes et laitons médiévaux: Histoire, archéologie et archéométrie des productions en laiton, bronze et autres alliages à base de cuivre dans l'Europe médiévale (12e-16e siècles). Medieval copper, bronze and brass: History, archaeology and archaeometry of the production of brass, bronze and other copper alloy objects in medieval Europe (12th-16th centuries). Actes du colloque de Dinant et Namur, 15-17 mai 2014. Proceedings of the symposium of Dinant and Namur, 15-17 May 2014. Études et documents, Archéologie 39. Namur: Agence wallonne du Patrimoine; 2018. p. 155-167. https://www.researchgate.net/publication/ 331299094. Accessed 4 Apr 2021.

52. Antoni D. The Oldest Hand-held Firearms from Slovakia. Studia Universitatis Cibiniensis. Series Historica 2013;10:111-127. https://www.academia. edu/8794059/. Accessed 4 Apr 2021.

53. Rathgen B. Das Geschütz im Mittelalter (The gun in the Middle Ages). Berlin:VDI-Verlag; 1928. https://archive.org/details/RathgenDasGesch uetzlmMittelalter/page/n9/mode/2up. Accessed 4 Apr 2021.

54. Ansani F. The Life of a Renaissance Gunmaker. Bonaccorso Ghiberti and the Development of Florentine Artillery in the Late Fifteenth Century. Technology and Culture. 2017;58:749-789. https://www.academia.edu/ 25081171/. Accessed 4 Apr 2021.

55. Lazar T. The Slovenian lands as the armed frontier of the Holy Roman Empire. Fasciculi Archaeologiae Historicae. 2017;30:59-72. https://doi. org/10.23858/FAH30.2017.006.

56. Scott D, Schwab R. Metallography in Archaeology and Art. Cult Herit Sci. 2019. https://doi.org/10.1007/978-3-030-11265-3.

57. Buchwald VF. Iron and steel in ancient times. Historisk-filosofiske Skrifter 29. Copenhagen: The Royal Danish Academy of Sciences and Letters; 2005.

58. Valério P, Monge Soares A, Araújo MF, Silva RJC, Porfírio E, Serra M. Arsenical copper and bronze in Middle Bronze Age burial sites of southern Portugal: the first bronzes in Southwestern Iberia. J Archaeol Sci. 2014;42:68-80. https://doi.org/10.1016/j.jas.2013.10.039.

59. Mihajlovič I. 4.2. The Ordnance. In: C Beltrame, S Gelichi, I Miholjek, editors. Sveti Pavao Shipwreck. A $16^{\text {th }}$ Century Venetian Merchantman from Mljet, Croatia. Oxford: Oxbow Books; 2014. p. 53-63. https:// iris. unive. it/ retri eve/ handle/ 10278/ 39554/29994/ Sveti Pavao Shipw reck PRINT ER File29. 05. 14. pdf.. Accessed 18 Dec 2020.

60. Morin M. Morphology and constructive techniques of Venetian artilleries in the $16^{\text {th }}$ and $17^{\text {th }}$ centuries: some notes. In: C Beltrame, RG. Ridella, editors. Ships \& Guns. The sea ordnance in Venice and Europe between the 15th and the 17th centuries. Oxford: Oxbow Books; 2011. p 1-11. https:// www.academia.edu/6005532/. Accessed 4 Apr 2021.

61. Bourgarit D, Thomas N. Late medieval copper alloying practices: a view from a Parisian workshop of the 14th century AD. J Archaeol Sci. 2012;39:3052-70. https://doi.org/10.1016/j.jas.2012.04.009.

62. Pernicka E. Provenance determination of archaeological metal objects. Memorie del Museo Civico di Storia Naturale di Verona. 2. serie. Sezione Scienze dell'Uomo. 2011;11:27-37. http://archiv.ub.uni-heidelberg.de/ propylaeumdok/4720/1/Pernicka_Provenance_determination_2011.pdf. Accessed 17 Feb 2021.

63. Pernicka E. Chapter 11: Provenance determination of archaeological metal objects. In: BW Roberts, C Thornton, editors. Archaeometry in Global Perspectives. Methods and Syntheses. Springer; 2014, p. 239-268. https://doi.org/10.1007/978-1-4614-9017-3_11.

64. Pollard AM, Bray P. A new method for combining lead isotope and lead abundance data to characterize archaeological copper alloys. Archaeometry. 2015;57(6):999-1008. https://doi.org/10.1111/arcm.12145.

65. Hauptmann A, Schmitt-Strecker S, Begemann F, Palmieri A. Chemical composition and lead isotopy of metal objects from the "Royal" tomb and other related finds at Arslantepe, Eastern Anatolia. Paléorient. 2002;28:4369. https://doi.org/10.3406/paleo.2002.4745.

66. Niederschlag E, Pernicka E, Seifert T, Bartelheim M. The determination of lead isotope ratios by multiple collector ICP-MS: a case study of early 
Bronze Age artefacts and their possible relation with ore deposits of the Erzgebirge. Archaeometry. 2003;45:61-100. https://doi.org/10.1111/14754754.00097.

67. Lutz J, Pernicka E. Prehistoric copper from the Eastern Alps. Open J Archaeometry. 2013;1:e25. https://doi.org/10.4081/arc.2013.e25.

68. Artioli G, Angelini I, Tecchiatti U, Petrotti A. Eneolithic copper smelting slags in the Eastern Alps: local patterns of metallurgical exploitation in the Copper Age. J Archaeol Sci. 2015;63:78-83. https://doi.org/10.1016/j. jas.2015.08.013.

69. Artioli G, Angelini I, Nimis P, Villa IM. A lead-isotope database of copper ores from the Southeastern Alps: a tool for the investigation of prehistoric copper metallurgy. J Archaeol Sci. 2016;75:27-39. https://doi.org/10. 1016/j.jas.2016.09.005.

70. Pryce TO, Baron S, Bellina BHM, Bellwood PS, Chang N, Chattopadhyay P, Dizon E, Glover IC, Hamilton E, Higham CFW, Kyaw AA, Natapintu S, Nguyen V, Pautreau JP, Pernicka E, Pigott VC, Pollard M, Pottier C, Reinecke R, Sayavongkhamdy T, Souksavatdy V, White J. More questions than answers: the Southeast Asian lead isotope project 2009-2012. J Archaeol Sci. 2014;42(1):273-94. https://doi.org/10.1016/j.jas.2013.08.024.

71. Pollard A, Bray P, Cuénod A, Hommel P, Hsu Y, Liu R, Perucchetti L, Pouncett J, Saunders M. Previous approaches to the chemistry and provenance of archaeological copper alloys. In: iid. Beyond provenance: new approaches to interpreting the chemistry of archaeological copper alloys. Leuven: Leuven University Press; 2018. p. 13-40. https://doi.org/10.2307/j. ctv7xbs5r.4.

72. Rademakers FW, Rehren T, Pernicka E. Copper for the Pharaoh: identifying multiple metal sources for Ramesses' workshops from bronze and crucible remains. J Archaeol Sci. 2017;80:50-74. https://doi.org/10.1016/j. jas.2017.01.017.

73. Siklósi Z, Szilágyi M. New data on the provenance of copper finds from the Early-Middle Copper Age of the Great Hungarian Plain. Archaeol Anthropol Sci. 2019;11(10):5275-85. https://doi.org/10.1007/ s12520-019-00867-8.

74. Nørgaard HW, Pernicka E, Vandkilde H. On the trail of Scandinavia's early metallurgy: provenance, transfer and mixing. PLOS ONE. 2019;14(7):e0219574. https://doi.org/10.1371/journal.pone.0219574.

75. Kowalski Ł, Garbacz-Klempka A, Gackowski J, Ścibiór D, Perek-Nowak M, Adamczak K, Długosz P. Towards direct casting: Archaeometallurgical insight into a bronze mould from Elgiszewo, Poland, 900-700 BC. Archeol Rozhl. 2019;71:45-66. https://www.arup.cas.cz/wp-content/uploads/ 2020/10/03_Kowalski_45-66_web.pdf. Accessed 19 Feb 2021.

76. Radivojević M, Roberts BW, Pernicka E, Stos-Gale Z, Martinón-Torres M, Rehren T, Bray B, Brandherm D, Ling J, Mei J, Vandkilde H, Kristiansen K, Shennan SJ, Broodbank C. The provenance, use, and circulation of metals in the European Bronze Age: the state of debate. Jour Archaeol Res. 2019;27:131-86. https://doi.org/10.1007/s10814-018-9123-9.

77. Tylecote RF. A History of Metallurgy. 2nd ed. London: Maney Publishing; 1992.

\section{Publisher's Note}

Springer Nature remains neutral with regard to jurisdictional claims in published maps and institutional affiliations.

\section{Submit your manuscript to a SpringerOpen ${ }^{\circ}$ journal and benefit from:}

- Convenient online submission

- Rigorous peer review

- Open access: articles freely available online

- High visibility within the field

- Retaining the copyright to your article

Submit your next manuscript at $\boldsymbol{\nabla}$ springeropen.com 